\title{
Study of the global and regional climatic impacts of ENSO magnitude using SPEEDY AGCM
}

\author{
Muhammad Mubashar Dogar ${ }^{1,2, *}$ (D, Fred Kucharski ${ }^{3}$ and Syed Azharuddin ${ }^{4}$ \\ ${ }^{1}$ Earth Science and Engineering Department, King Abdullah University of Science and Technology, \\ Thuwal, Saudi Arabia. \\ ${ }^{2}$ Global Change Impact Studies Centre (GCISC), Ministry of Climate Change, Islamabad, Pakistan. \\ ${ }^{3}$ Abdus Salam International Centre for Theoretical Physics, Earth System Physics Section, \\ Strada Costiera 11, 34151 Trieste, Italy. \\ ${ }^{4}$ Birbal Sahni Institute of Palaeosciences, 53 University Road, Lucknow 226 007, India. \\ *Corresponding author.e-mail: mubashardogar@yahoo.com; muhammad.dogar@kaust.edu.sa
}

ENSO is considered as a strong atmospheric teleconnection that has pronounced global and regional circulation effects. It modifies global monsoon system, especially, Asian and African monsoons. Previous studies suggest that both the frequency and magnitude of ENSO events have increased over the last few decades resulting in a need to study climatic impacts of ENSO magnitude both at global and regional scales. Hence, to better understand the impact of ENSO amplitude over the tropical and extratropical regions focussing on the Asian and African domains, ENSO sensitivity experiments are conducted using ICTPAGCM ('SPEEDY'). It is anticipated that the tropical Pacific SST forcing will be enough to produce ENSO-induced teleconnection patterns; therefore, the model is forced using NINO3.4 regressed SST anomalies over the tropical Pacific only. SPEEDY reproduces the impact of ENSO over the Pacific, North and South America and African regions very well. However, it underestimates ENSO teleconnection patterns and associated changes over South Asia, particularly in the Indian region, which suggests that the tropical Pacific SST forcing is not sufficient to represent ENSO-induced teleconnection patterns over South Asia. Therefore, SST forcing over the tropical Indian Ocean together with air-sea coupling is also required for better representation of ENSO-induced changes in these regions. Moreover, results obtained by this pacemaker experiment show that ENSO impacts are relatively stronger over the Inter-Tropical Convergence Zone (ITCZ) compared to extratropics and high latitude regions. The positive phase of ENSO causes weakening in rainfall activity over African tropical rain belt, parts of South and Southeast Asia, whereas, the La Niña phase produces more rain over these regions during the summer season. Model results further reveal that ENSO magnitude has a stronger impact over African Sahel and South Asia, especially over the Indian region because of its significant impact over the tropical Atlantic and the Indian Ocean through Walker circulation. ENSO-induced negative (positive) NAO-like response and associated changes over Southern Europe and North Africa get significantly strong following increased intensity of El Niño (La Niña) in the northern (southern) hemisphere in the boreal winter (summer) season. We further find that ENSO magnitude significantly impacts Hadley and Walker circulations. The positive phase of ENSO (El Niño) overall strengthens Hadley cell and a reverse is true for the La Niña phase. ENSO-induced strengthening and weakening of Hadley cell induces significant impact over South Asian and African ITCZ convective regions through modification of ITCZ/monsoon circulation system.

Keywords. ENSO; NAO; MENA; Hadley circulation; ITCZ; monsoon system. 


\section{Introduction}

El Niño-Southern Oscillation (ENSO) is an inter-annual climate variability pattern associated with an irregular periodic fluctuation of winds, sea surface temperatures and air pressure over the equatorial Pacific Ocean, affecting much of the tropics and subtropics (Neelin et al. 1998; Trenberth et al. 1998; Timmermann et al. 1999; Trenberth and Caron 2000; Lee et al. 2010; Lee 2012; Zhang et al. 2011). The warming phase of this inter-annual climate variability is known as El Niño and the cooling phase as La Niña. Both the phases have worldwide climatic influence with important ecological and socio-economic consequences (Timmermann et al. 1999). The physical link between ENSO variation and subsequent temperature and precipitation responses at global and regional scale has been documented in many studies (Trenberth et al. 1998; Timmermann et al. 1999; Diaz et al. 2001; Ashok et al. 2001, 2004; Molteni et al. 2003; Bracco et al. 2007; Kripalani et al. 2007; Kucharski et al. 2013a, b). Several past studies have shown a strong teleconnnection relationship between eastern and central equatorial Pacific sea surface temperature variability and rainfall pattern over Pacific, Atlantic and Indian Ocean and associated continental regions focusing Southeast Asia and Africa (Rasmusson and Carpenter 1983; Lee et al. 2010; Zhang et al. 2011, 2012, 2013; Wang et al. 2012; Karori et al. 2013; Kucharski et al. 2013a, b). Many recent studies have shown that Asian, Indian and Australian monsoon systems are greatly influenced by the ENSO variation (Lau and Nath 2000; Bracco et al. 2007; Kripalani et al. 2007; Lean and Rind 2008). ENSO is known as the largest climatic forcing which deals with variability of interannual monsoon through the large-scale east-west displacement of heat transfer in the tropics (Kumar et al. 1999a). Numerous studies have shown the simultaneous association of ENSO indices and the monsoonal rainfall over India (Pant and Parthasarathy 1981; Ashok et al. 2001, 2004; Kripalani et al. 2007). Using observations and reanalysis products, Singh et al. (2013) have examined the mechanisms governing the teleconnections associated with prolonged La Niña variability in the Indian Ocean SST anomaly with a special emphasis on southwest tropical Indian Ocean SST. Their study concludes that winter (boreal) SST is highly influenced by long-lived La Niña forcing which indicates the importance of tropical Indian Ocean SST in addition to tropical Pacific SST for better representation of ENSO-induced teleconnections. A possible physical association between the Indian monsoon system and ENSO teleconnection based on the idea of large scale dynamic circulation was first suggested by Sir Gilbert Walker (Walker 1925). Afterwards, numerous studies have shown that the warm phase (El Niño) is associated with a weakening of the Indian monsoon system with an overall reduction in rainfall (Bhalme and Mooley 1980; Rasmusson and Carpenter 1983; Shukla and Paolino 1983; Ju and Slingo 1995; Ashok et al. 2001, 2004), conversely, the cold phase (La Niña) is associated with the strengthening of the Indian monsoon system and the enhancement of rainfall (Shukla and Paolino 1983; Ju and Slingo 1995). However, other studies have also discussed the variations in the relationships between monsoonal rainfall and its predictors (Parthasarathy et al. 1991, 1992, 1994; Ashok et al. 2001). These variations have been attributed to change in ENSO characteristics such as period and amplitude (Kumar et al. 1999b).

In the past couple of decades, there have been increased occurrences of both frequency and magnitude of El Niño events with maximum warming anomaly occurring in the central and eastern equatorial Pacific (e.g., Latif et al. 1997; Lee et al. 2010; Karori et al. 2013), called as Central Pacific (CP) El Niño (Kao and Yu 2009; Yu and Kim 2010), dateline El Niño (Larkin and Harrison 2005), warm pool El Niño (Kug et al. 2009), or El Niño Modoki (Ashok et al. 2007). While previous studies on ENSO events have discussed an increasing frequency of El Niño and La Niña events in recent decades (Timmermann et al. 1999; Yeh et al. 2009; Lee et al. 2010), changes in the magnitude of El Niño and La Niña events have not been discussed much. Therefore, there is a need to study the impact of the intensity of both phases of ENSO, i.e., El Niño and La Niña. Being prominent mode of interannual variability, ENSO produces profound impacts on global and regional climate; hence, there is a great interest in studying as to how the changing intensity and magnitude of the tropical Pacific sea surface temperature would affect tropical global circulations and associated changes in temperature and precipitation distribution. Although, the intensity of Hadley cell and its sensitivity to ENSO episodes has been intensely addressed (Held and Hou 1980; Seager et al. 2003; Feng and Li 2013; Nguyen et al. 2013), however, questions remain, as how this thermally driven large scale tropical circulation will respond to ENSO increased amplitude and associated changes in surface air temperature and precipitation patterns. For this purpose, we will make use of an atmospheric climate model of intermediate complexity, i.e., ICTP-AGCM that has effectively been used previously to study global and regional climatic changes (Kucharski et al. 2006a, b, 2013a, b; Bracco et al. 2007; Bulić and Branković 2007). In this study, we will see how well it can reproduce the impact of ENSO events at global and regional levels. The main purpose of studying the 
magnitude of ENSO events is to investigate the impact of ENSO (El Niño and La Niña) magnitude on Hadley circulation and subsequent temperature and precipitation distribution at global and regional scales focussing over the tropical and extra-tropical regions. We will also revisit ENSOinduced variation in Indian and African rainfall in summer (JJA) season as this region is getting a lot of interest because of its sensitivity and droughtlike condition to such events (Zeng 2003; Giannini et al. 2008; Kucharski et al. 2013a, b). In addition, we will also revisit previously known facts of ENSO teleconnection pattern over Pacific and Atlantic regions such as ENSO-induced NAO pattern over North Atlantic region and its climatic effect over Europe and Middle East region.

Therefore, the current paper deals with an ENSO (El Niño/La Niña) varying magnitude and associated climatic impacts over the tropical and extratropical regions, especially over South Asian and African convective regions. The study also deals with the ENSO-induced strengthening and weakening of Hedley cell that causes significant impact over Indian and African monsoons during summer. The rest of the paper is organized as follows. Section 2 discusses material and methods including the description of the model used in this study. ENSO phases and their global and regional impacts in winter and summer seasons are described in section 3 . In the last section, we summarize our results.

\section{Material and methods}

\subsection{Model description}

Some of the main progress for studying the ENSO events and their global and regional impacts came initially from models of intermediate complexity, which are sufficiently detailed to compare to observations and to use in prediction but are less complex than coupled general circulation models (Neelin et al. 1998). Keeping in mind, the ideal use of intermediate complexity model for such studies, the numerical experiments used in this study are conducted using version 41 of the atmospheric general circulation model developed at the Abdus Salam International Center for Theoretical Physics (ICTP), also known as SPEEDY (Simplified Parametrizations, primitivE-Equation DYnamics) ICTPAGCM (Kucharski et al. 2006a, b, 2013a, b). SPEEDY is a model of intermediate complexity having a facility to be coupled with a thermodynamic slab-ocean layer (with a depth that varies between $60 \mathrm{~m}$ in the extra-tropical and $40 \mathrm{~m}$ in the tropical regions) that mimics air-sea interaction. It uses a hydrostatic spectral dynamical core developed at GFDL (see, Held and Suarez 1994) in the vorticity-divergence form as described by Bourke (1974). The parameterization processes used in the model include short and longwave radiations, largescale condensation, convection, surface fluxes of momentum, heat and moisture, and vertical diffusion. Boundary layer fluxes in the model are obtained by stability-dependent bulk formulae and convection process is represented by a mass flux scheme that is activated where conditional instability is present. Furthermore, a simple one layer thermodynamic model is used to determine temperature anomalies for land and sea ice (Kucharski et al. 2006a, b, 2013a, b). ICTPAGCM is computationally inexpensive due to its low resolution and simplified parameterizations and is very flexible as it can be easily modified to address a wide range of problems used to understand basic states of the climatic system. In recent couple of years, ICTPAGCM has been used effectively in climate modeling research to study broad range of topics, such as modes of extra-tropical planetary scale variability (Molteni et al. 2011); extra-tropical circulation trends and decadal changes (Kucharski et al. 2006a, b); tropical/extra-tropical teleconnections; monsoon climate and its variability; ENSO monsoon relationships and their decadal changes; tropical teleconnection patterns (Kucharski et al. 2007; Barimalala et al. 2012) and ENSO teleconnection changes in global warming scenarios (Bulić et al. 2012). In almost all these studies, SPEEDY has performed reasonably well and reproduced climate statistics within the range of observed changes. The latest eight vertical layers version of this model is improved significantly compared with previous five layers version. An updated description of the latest version, having eight vertical layers, used in this study as well as previous model versions including list of users and downloading information can be seen at http://users.ictp.it/ kucharsk/speedy-net. html. A detailed documentation of the SPEEDY ICTPAGCM having five vertical layers together with its climatology and variability can be found in Molteni (2003).

\subsection{Experimental design and methodology}

To investigate the global and regional scale climatic impact of ENSO forcing, four sets of ENSO experiments and a control (neutral) experiment at T30 spectral truncation resolution $\left(\sim 3.75^{\circ} \times 3.75^{\circ}\right.$ horizontal resolution) are conducted. Two experiments are designed for El Niño phase and two for La Niña phase. For ENSO (El Niño/La Niña), the forcing that is used is a climatological SST field derived as monthly mean over the period 1979-2008 from ERA-Interim data, plus a Nino3.4 anomaly (added over the tropical Pacific region 
only) that was derived as monthly mean regression of National Oceanic and Atmospheric Administration's (NOAA) Extended Reconstructed Sea Surface Temperature, version 3 (ERSST.v3) dataset (Smith et al. 2008) onto the normalized Niño3.4 index for the period 1950-2010. El Niño events correspond to all the positive regression maps in the regressed anomaly pattern. To double the magnitude of the El Niño forcing, we simply doubled the Nino3.4-based regressed climatological SST anomaly over the tropical Pacific region only. The La Niña experiments share the opposite conditions to El Niño, i.e., these are prepared using same SST conditions as for El Niño by multiplying with -1 and -2 to make them one time and two times of La Niña amplitude, respectively. The advantage of choosing El Niño and La Niña pattern in this particular style (same pattern with opposite signs) could be that we can study the nonlinearity in the responses to El Niño and La Niña, if the responses are not exactly the same with opposite sign. In addition to these El Niño and La Niña experiments, we have conducted a control experiment that roughly corresponds to neutral ENSO state. This control experiment just uses the monthly SST climatology from 1979 to 2008 from ERA-Interim data. It is necessary to mention that our control and ENSO (El Niño/La Niña) experiments share the same background climatological SST forcing that is derived using ERAInterim data for the period 1979-2008. The only difference between control and ENSO (El Niño and La Niña) experiments is the additional Nino3.4 regressed SST pattern added over the tropical Pacific region as explained above. These are the SST boundary conditions, all other boundary conditions are monthly varying monthly climatologies derived from ERA-Interim (as is described in the SPEEDY AGCM description). Therefore, the only forcing in these simulations are the SSTs. As for the initial conditions, the model starts from rest and we have disregarded the first year to avoid spin-up effects. For all the experiments (control as well as El Niño/La Niña), we run the model for 50 years period in order to minimize any possible internal atmospheric variability. If there was no internal atmospheric variability or 'noise', then we could just run for one year (as we used climatological SST as boundary condition), but since there is a noise (due to all kinds of instabilities and nonlinearities we have in the atmosphere, e.g., baroclinic instability), in order to get a good estimate of the ENSO-induced, forced component or signal, we have to reduce this noise. In this study, we did it by interpreting the 50 years of integration as 50 independent ensemble realizations. The total response in one realization will be composed of a signal and a noise (their variances are additive). Our best estimate of the (ENSO) signal is to calculate the ensemble mean of these 50 responses. The impact of ENSO (El Niño and La Niña) magnitude is calculated as a simple departure of the forced (El Niño or La Niña) experiment from the control experiment in winter (DJF) and summer (JJA) seasons and results are displayed as composited anomalies calculated by averaging/compositing over entire 50 years of the simulation period for winter and summer seasons, respectively. We have also used Climate Forecast System Reanalysis (CFSR) data (1979-2008 period) for comparison and validation of model produced climatological pattern. CFSR is a high-resolution ( $\sim 38 \mathrm{~km}$ horizontal grid spacing) reanalysis produced using NCEP coupled atmosphere-ocean-land surface-sea ice model (Saha et al. 2010).

We anticipate that the tropical Pacific SST forcing will be enough to produce ENSO-induced teleconnection patterns (as ENSO teleconnections are mainly Pacific-induced). Therefore, we designed our ENSO (El Niño/La Niña) experiments by forcing the model using Nino3.4 regressed SST anomalous conditions over the tropical Pacific region only (SST forcing over the rest of the regions is same as in control). This setting will answer whether ENSO-based teleconnection patterns can be better represented by SST changes over the tropical Pacific Ocean only, or we need to include ENSO-induced changes in all the global oceans, in particular, the Indian and Atlantic Oceans.

\section{Results and discussion}

\subsection{Winter response}

Figure 1 shows winter (DJF) season SST mean anomaly both for one time and two times El Niño and La Niña conditions (hereafter referred as $1 \times$ and $2 \times$ ) considered over the tropical Pacific Ocean. Anomaly is calculated by subtracting $1 \times$ and $2 \times \mathrm{El}$ Niño and La Niña experiments from corresponding control simulation. Spatial pattern of SST (both for El Niño and La Niña) shows that SST anomalous response is well represented in ICTP-SPEEDY model. It shows warm pool over eastern and central Pacific and associated cold anomaly over western Pacific for El Niño case and inverse relationship is true for La Niña forcing. These are the winter season mean SST anomalies that are used as input boundary conditions in SPEEDY AGCM perturbed experiments $(1 \times$ and $2 \times \mathrm{El}$ Niño and La Niña). Spatial pattern of SST anomalies shows that the magnitude of tropical Pacific SST anomalies are approximately doubled for $2 \times \mathrm{El}$ Niño and La Niña episodes compared to their $1 \times$ counterpart. Figure 2 shows simulated global mean pattern of 2 -m surface air temperature and precipitation 
$1 *$ El Nino-Control

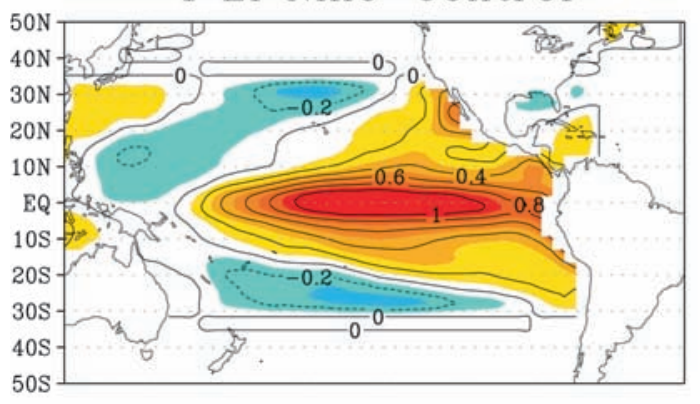

$1 *$ La Nina-Control

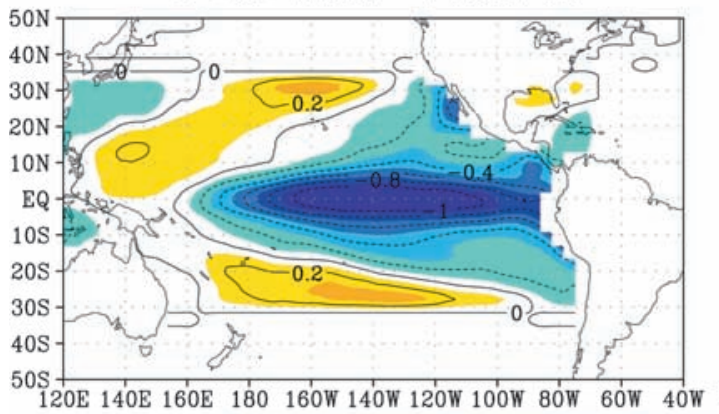

$2 *$ El Nino-Control

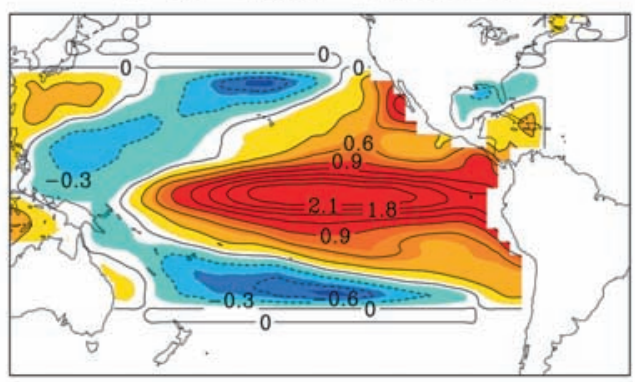

$2 *$ La Nina-Control

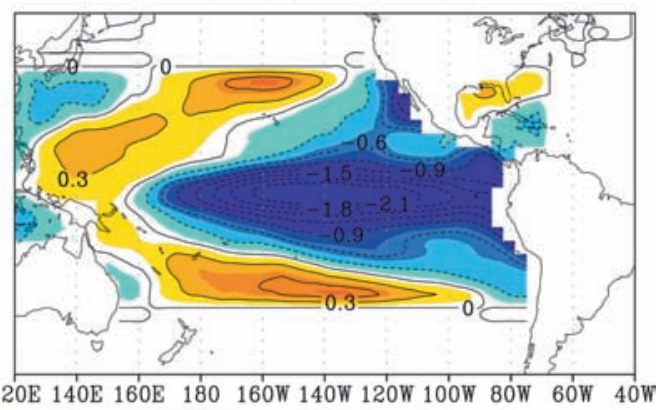

$-0.9$

$-0.7$

\begin{tabular}{ll|l}
1 & & \\
-0.5 & -0.3
\end{tabular}

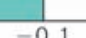

0.1

0.3

0.5

0.7

0.9

Figure 1. Mean SST anomaly pattern (experiment-control) in winter (DJF) season.

overlaid with mean pattern of zonal and meridional wind vectors at $925 \mathrm{hPa}$ in winter season produced using SPEEDY control experiment and CFS reanalysis. Spatial structure of mean surface air temperature and precipitation clearly demonstrates that SPEEDY AGCM replicates effectively to the main features such that it exhibits higher temperature pattern over the tropical regions and cooling patterns in high latitude polar regions. Precipitation and wind vector patterns are also well produced by model. Converging and diverging wind patterns at the tropical region, as well as low pressure areas and associated cyclonic features in the northern Atlantic and the northern Pacific regions are consistent among SPEEDY simulation and CFS reanalysis product. This analysis increased our confidence in the usage of SPEEDY model. To better assess ENSO-induced teleconnection patterns, we have to analyze anomalous atmospheric responses following both El Niño and La Niña events by evaluating composited differences between ENSO and control experiments performed using SPEEDY model. Figure 3 shows the global anomalous response of $2-\mathrm{m}$ surface air temperature for both $1 \times$ and $2 \times$ El Niño (top) and La Niña forcing (bottom). Both the $1 \times$ and $2 \times \mathrm{El}$ Niño are showing a strong warming over North America (eastern and central America) as well as over the Arabian peninsula and African region. However, we noticed a strong cooling impact over
Eastern Eurasia, Australia and South Asia. A reverse anomalous pattern is observed in La Niña episodes (both $1 \times$ and $2 \times$ ). This ENSO-induced $(\mathrm{El}$ Niño/La Niña) tropical warming/cooling pattern extending to Arctic and North American regions is caused by a well known ENSO-induced tropically excited Arctic warming/cooling mechanism following El Niño/La Niña forcing scenario. In this tropically excited Arctic mechanism (TEAM), the poleward propagating Rossby waves can warm/cool the Arctic through adiabatic warming/cooling mechanism, an enhanced poleward stationary eddy heat transport, and downward infrared (IR) radiation (Saravanan 1993; Lee 2012 and references therein). We also notice strong El Niño/La Niña induced warming/cooling pattern over tropical Africa that are largely caused by large-scale dynamic circulation and associated diabatic processes driven by Walker circulation. Another mechanism of this African continent heating/cooling could be explained through convectively generated Rossby waves. These waves emanate from the equatorial Pacific, moving eastward along circular paths resulting in wind and pressure changes that consequently play key role in the transport of heating/cooling over these regions and towards extra-tropics (Saravanan 1993; Jin and Hoskins 1995; Kiladis et al. 2009; Lee 2012). Temperature anomalies induced by $2 \times \mathrm{El}$ Niño forcing are much stronger than $1 \times \mathrm{El}$ Niño forcing. The 

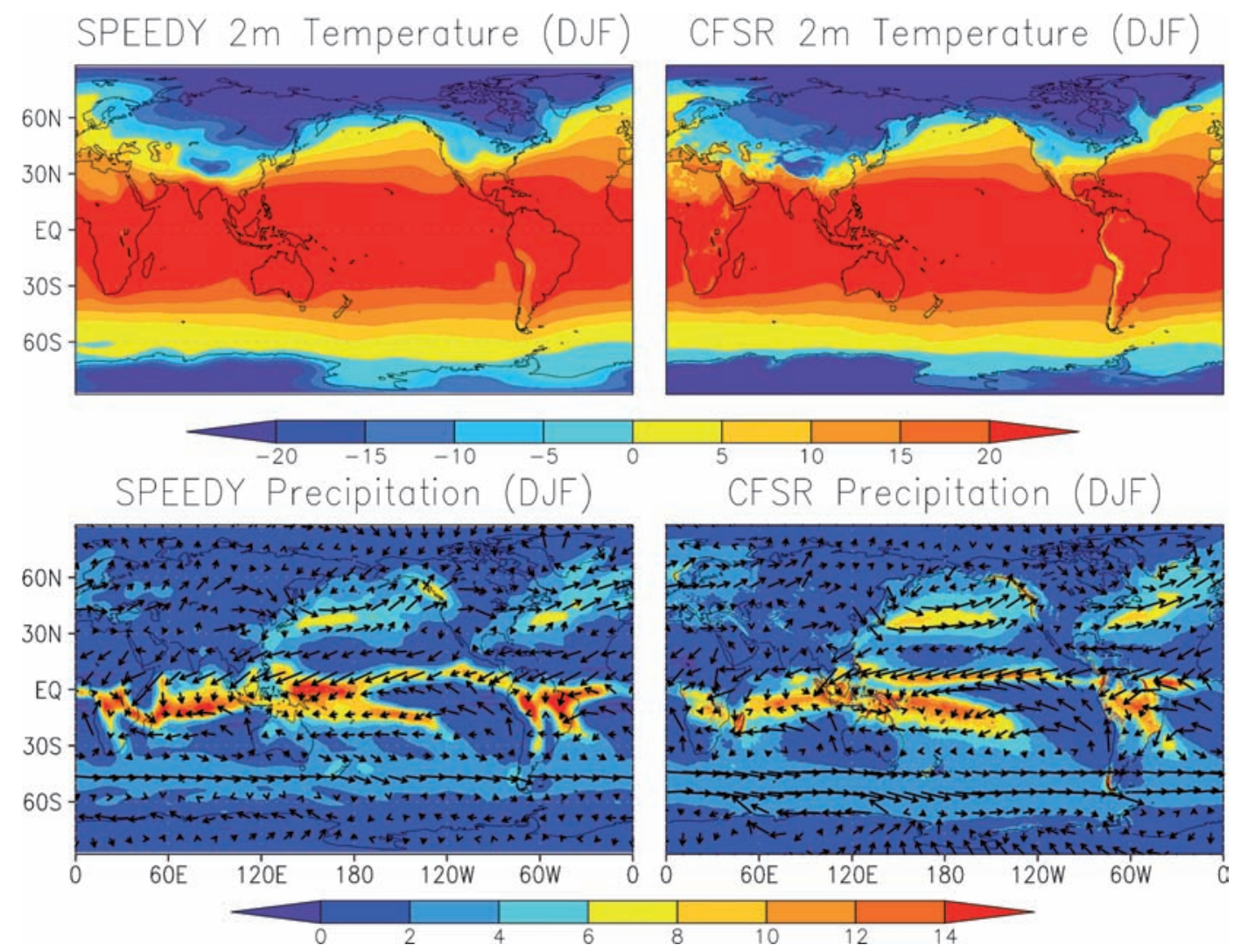

Figure 2. Ensemble mean spatial pattern of 2 -m surface air temperature $\left({ }^{\circ} \mathrm{C}\right)$ and precipitation $(\mathrm{mm} / \mathrm{d})$ overlaid with ensemble mean wind vectors at $925 \mathrm{hPa}$ in winter (DJF) season from SPEEDY AGCM and CFS reanalysis.

anomalous 2-m surface air temperature response to the La Niña forcing is opposite to El Niño forcing. La Niña forcing will induce stronger cooling over North America, Europe, Arabian peninsula and African domain. From the spatial anomaly pattern of 2-m surface air temperature, we noticed that SPEEDY model reproduces the impact of ENSO over the Pacific, North and South America and African regions very well and our results are in agreement with earlier studies (Sterl et al. 2007; Lee 2012; Wang et al. 2012), however it underestimates ENSO teleconnection pattern and associated changes over Indian Ocean, covering Bay of Bengal and Laccadive Sea, Southeast Asia, in particular, over Indian and Sri Lankan domains which show that tropical Pacific SST forcing might not be the only necessary forcing responsible for ENSO-induced teleconnection patterns over Southeast Asian region and therefore, global SST forcing or at least Indian Ocean SST variability (Bracco et al. 2007; Singh et al. 2013) and interactive air-sea coupling in the Indian Ocean region (Lau and Nath 2000; Wang et al. 2005; Wu and Kirtman 2005; Bracco et al. 2007) might also be required for better representation of ENSO-induced changes over these regions.

Figure 4 shows the response of precipitation anomaly $(\mathrm{mm} / \mathrm{d})$ in winter season for both $1 \times$ and $2 \times$ El Niño and La Niña forcing experiment. The pattern of precipitation anomaly following both El Niño and La Niña shows a stronger signal over the tropical regions compared to extra-tropics. Spatial pattern of precipitation anomaly reveals that El Niño forcing causes increased precipitation anomaly over the east and central equatorial Pacific region and decreased precipitation anomaly in the western Pacific which is consistent with the warm anomaly over east and central equatorial Pacific and cold anomalous pattern in western part of Pacific respectively as is observed in SST and 2-m temperature pattern (figures 1 and 3). These warm (cold) surface features cause more (less) evaporation that results in increased (decreased) rainfall anomalies over the equatorial regions. We also noticed that El Niño-induced warm anomaly over the tropics causes more precipitation over the upward branch (also known as ITCZ) of the Hadley cell. Subtropical regions that fall within the downward or sinking branch of Hadley cell display decreased precipitation anomalies for both the $1 \times$ and $2 \times$ El Niño experiments. As latitudinal position of the rising and sinking limbs of local Hadley cell varies at regional scale (Schwendike et al. 2014), increasing and decreasing patterns of precipitation anomalies over the tropical region follow the position of ITCZ at regional scale. 

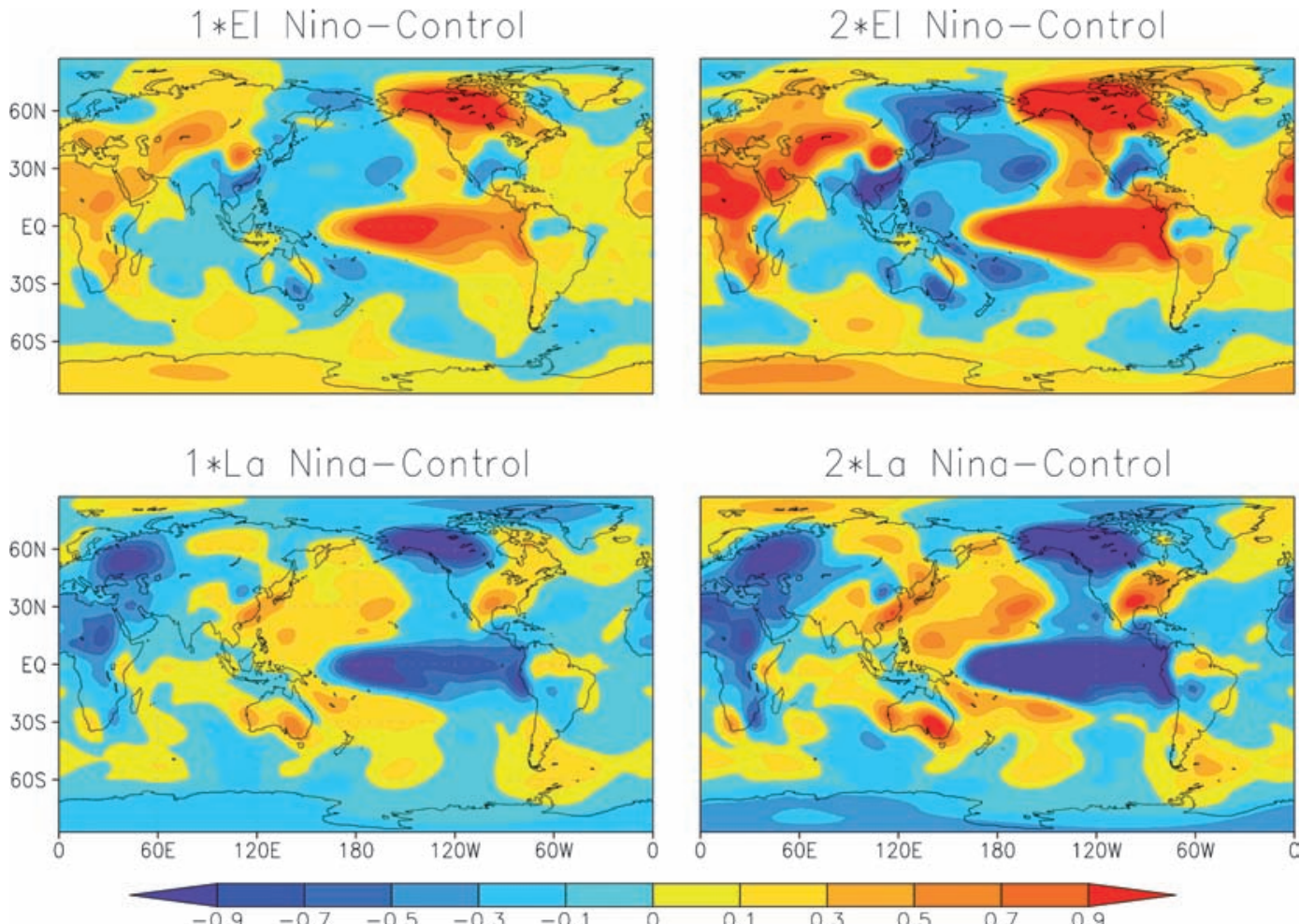

Figure 3. Ensemble mean response of 2-m surface air temperature anomaly pattern (experiment-control) following El Niño and La Niña forcing in winter (DJF) season.
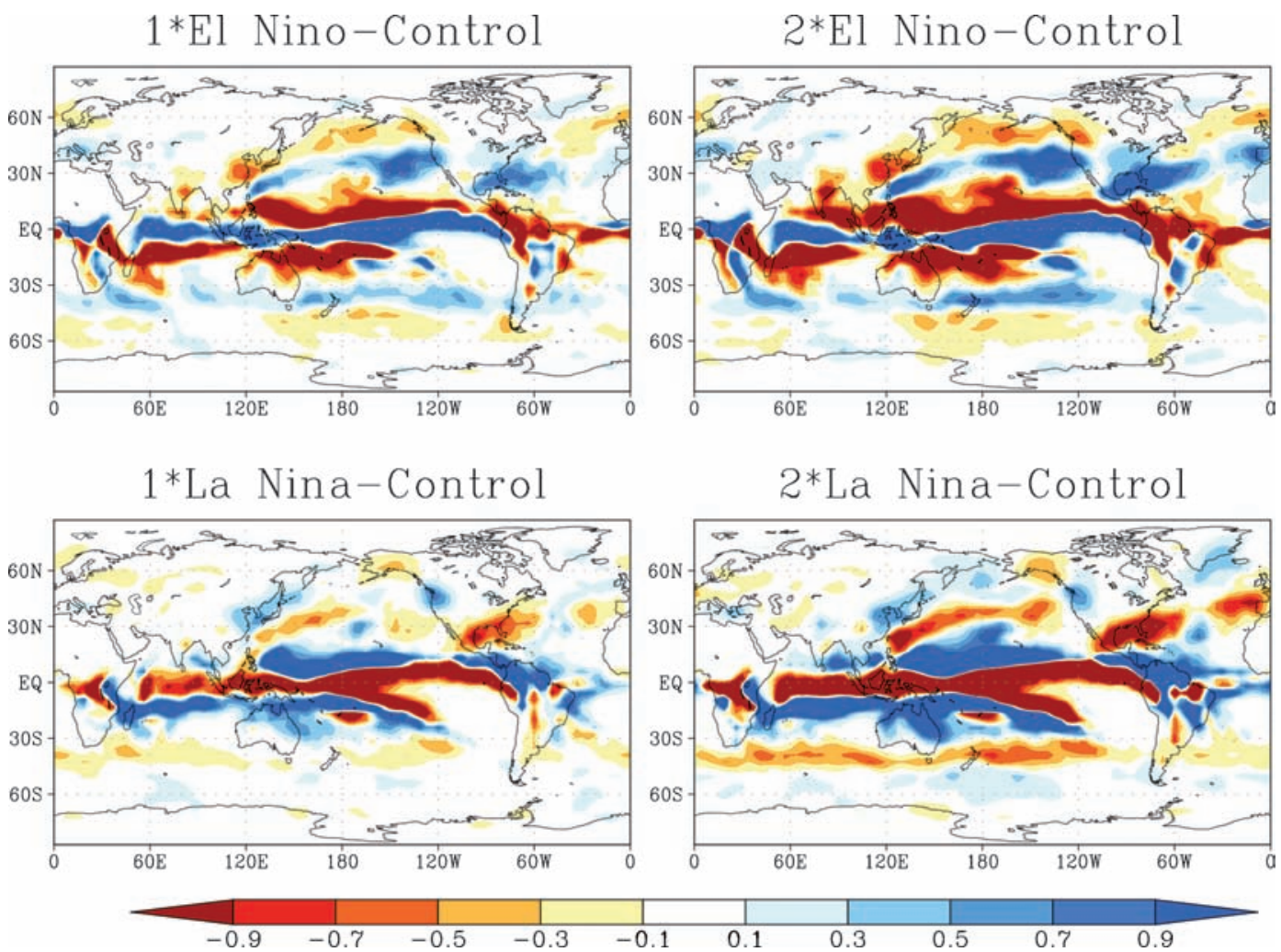

Figure 4. Ensemble mean response of precipitation $(\mathrm{mm} / \mathrm{d})$ anomaly (experiment-control) following El Niño and La Niña forcing in winter (DJF) season. 
Precipitation responses for $2 \times \mathrm{El}$ Niño forcing are much stronger than $1 \times$ El Niño case. A positive rainfall and cyclonic circulation response is seen near the California coast and Aleutian region as well as in the Gulf of Mexico, Cuba and Florida region, extending further into the western Atlantic. El Niño forcing also causes precipitation decrease over India, Australia, Sri Lanka, Thailand and Columbia. ENSO-induced winter precipitation anomaly for El Niño forcing is consistent with an earlier study showing a comparison between NCEP reanalysis precipitation anomaly and SPEEDY AGCM in which El Niño regressed rainfall anomaly pattern is shown using normalized Nino3.4 index onto winter precipitation (Sterl et al. 2007; Kucharski et al. 2013a, b). Although, overall pattern of ENSO-induced precipitation changes over global and regional scales is well reflected in SPEEDY simulation as it agrees well with an earlier study (Kucharski et al. 2013a, b), it lacks in fully reproducing changes over Indian and Southeast Asian domains in winter season. One of the possible reasons of this disparity could be that the SST forcing over the tropical Pacific might not be the only driving factor for major teleconnections. Therefore, SST forcing over tropical Indian Ocean and its associated teleconnection with tropical Pacific through large scale Walker circulation might also be required as additional important condition to fully characterize ENSOinduced changes over Asian region focussing Southeast Asia as Indian Ocean tropical SST could play significant role for governing teleconnections associated with tropical Pacific Ocean (Ashok et al. 2004; Bracco et al. 2007; Singh et al. 2013). Precipitation anomalies obtained for La Niña conditions are roughly opposite to El Niño impact. The intensity of precipitation response for $2 \times \mathrm{La}$ Niña phase increase almost linearly and is therefore much stronger than $1 \times$ La Niña phase. A dipole pattern of precipitation anomalies in high latitudes (between $30^{\circ}-60^{\circ} \mathrm{N}$ and $30^{\circ}-60^{\circ} \mathrm{S}$ ) following both El Niño and La Niña forcing experiment could be associated with the upward and downward branch of Ferrell cell.

In order to have a better idea of ENSO-induced changes in tropical Hadley circulation, we have plotted vertical velocity (Omega in $\mathrm{P} / \mathrm{sec}$ ) overlaid with rising and sinking air produced by globally zonal averaged meridional and vertical wind profile (figure 5). These results clearly reveal that both the El Niño and La Niña induce strong impact over the tropical atmospheric Hadley circulation as both the vertical velocity and the intensity of the wind

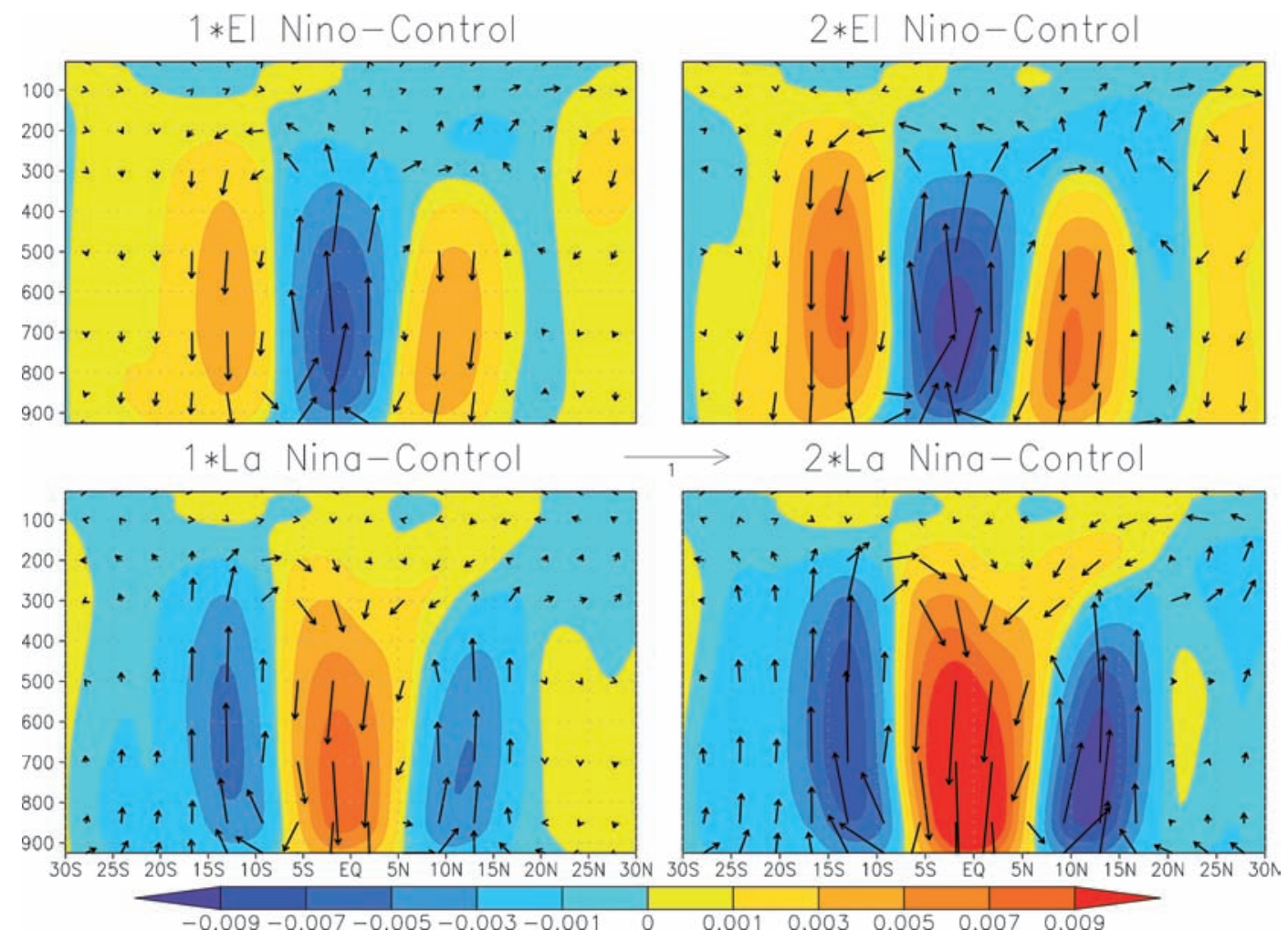

Figure 5. Ensemble mean anomaly (experiment-control) of zonal mean vertical velocity ( $\mathrm{Pa} / \mathrm{s}$; in shaded colours) in the latitude pressure plane with overlaid zonal mean wind vectors $(\mathrm{v} ;-100 *$ omega) $[\mathrm{m} / \mathrm{s} ; 100 * \mathrm{~Pa} / \mathrm{s}]$ anomaly response (experimentcontrol) following El Niño and La Niña forcing in winter (DJF) season. The length and direction of arrows depict the intensity $(\mathrm{m} / \mathrm{s})$ and direction of air movement in the latitude pressure plane, respectively. 
vectors have increased significantly following increased magnitude of El Niño event. We further noticed that El Niño induces strengthening and equatorward shift in Hadley cell circulation (sinking limbs are confined within $10-20^{\circ}$ latitude in both hemispheres) whereas La Niña causes weakening in the Hadley cell circulation. Response of Hadley cell following doubled forcing experiments both for El Niño and La Niña reveals that the magnitude of Hadley rising and sinking branches has significantly increased exhibiting that Hadley circulation is very sensitive to the magnitude of ENSO forcing. The spatial pattern clearly shows increased intensity of rising and sinking wind vector anomalies and associated vertical velocity pattern for enhanced El Niño (La Niña) forcing. We also analyzed pattern of zonally averaged zonal wind anomaly following El Niño and La Niña episodes in winter season (not shown) that shows that El Niño produces strengthening and equatorward shift to the jet streams. This ENSO-induced strengthening and equatorward shift of jet streams result into a narrower but intense Hadley cell (figure 5), because of increased eddy stress (Lee 2012). The results of La Niña are opposite to El Niño forcing.

Figures 6 and 7 show the response of mean sea level pressure and geopotential height (at $850 \mathrm{hPa}$ ) anomalies, respectively, following El Niño and La Niña phases for both the experiments $(1 \times$ and $2 \times)$ in winter season. During El Niño forcing, both the mean sea level pressure and geopotential height show a strong negative anomaly pattern over high latitude region $\left(30^{\circ}-60^{\circ} \mathrm{N}\right)$ in the Atlantic and Pacific Ocean and a signature of high anomalies over the tropical belt, particularly in the Indian Ocean that extends further to land areas of South and Southeast Asia (Sterl et al. 2007). Similarly, we observed signature of positive anomalies in high latitude polar regions. These anomalies of significant high and low pressure obvious in SLP and $850 \mathrm{hPa}$ geopotential height anomalous response further elongates zonally to Atlantic Ocean and resembles a negative NAO-like pattern over the Atlantic Ocean (Zhang et al. 2015). This North Atlantic, NAO-like ENSO response may be interpreted as an extension of the PNA pattern (e.g., Brönnimann et al. 2007; Bulić and Kucharski 2012), or it could be caused through a stratospheric pathway of ENSO teleconnections (e.g., Ineson and Scaife 2009). This negative NAO pattern produces (through pressure gradient-induced changes in the mean wind flow pattern) significant impact over northern and southern Europe extending to Middle East and North African (MENA) regions and induces warm and wet anomalies as seen in 2-m surface air temperature and precipitation (figures 3 and 4 respectively) patterns ( $\mathrm{Yu}$ and Zhou 2004). Again the La Niña phase displays inverse structure to the El
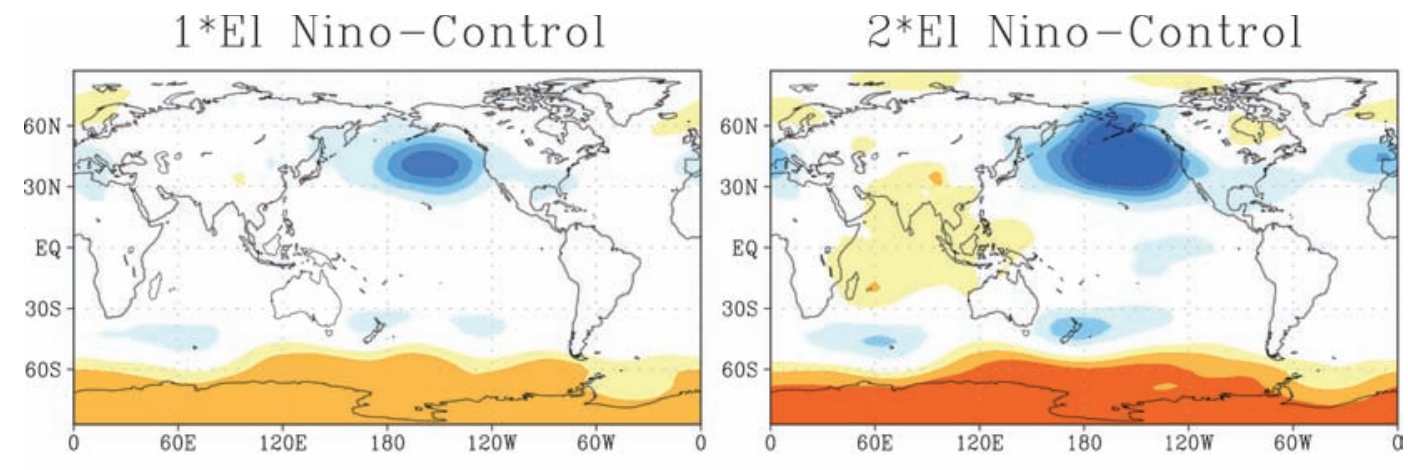

$1 *$ La Nina-Control

$2 *$ La Nina-Control

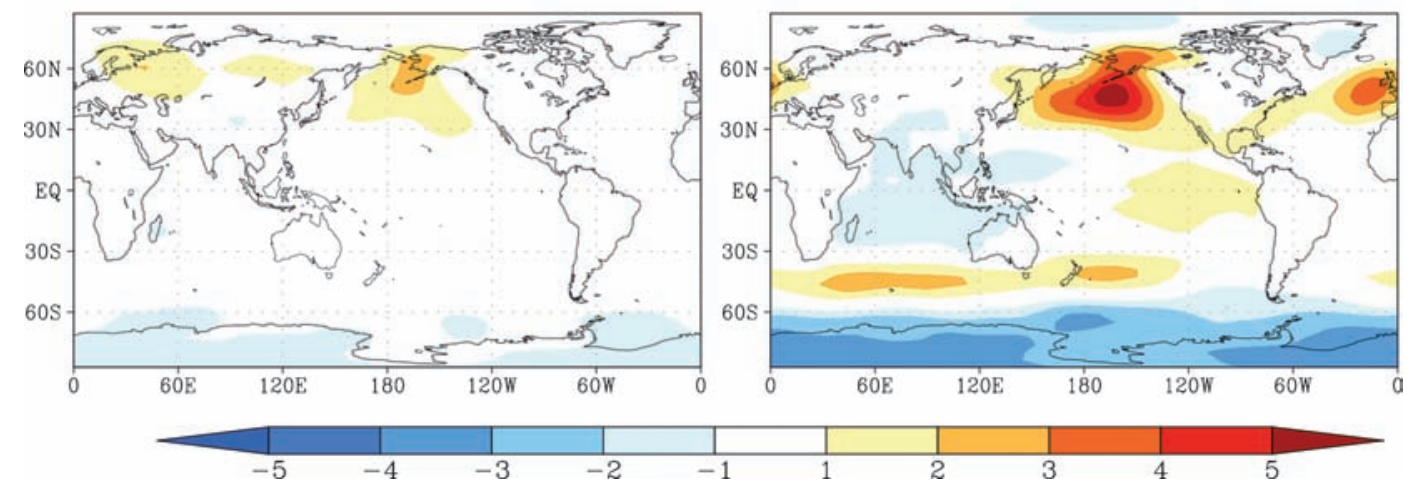

Figure 6. Ensemble mean response of mean sea level pressure (MSLP) anomaly (experiment-control) following El Niño and La Niña forcing in winter (DJF) season. 

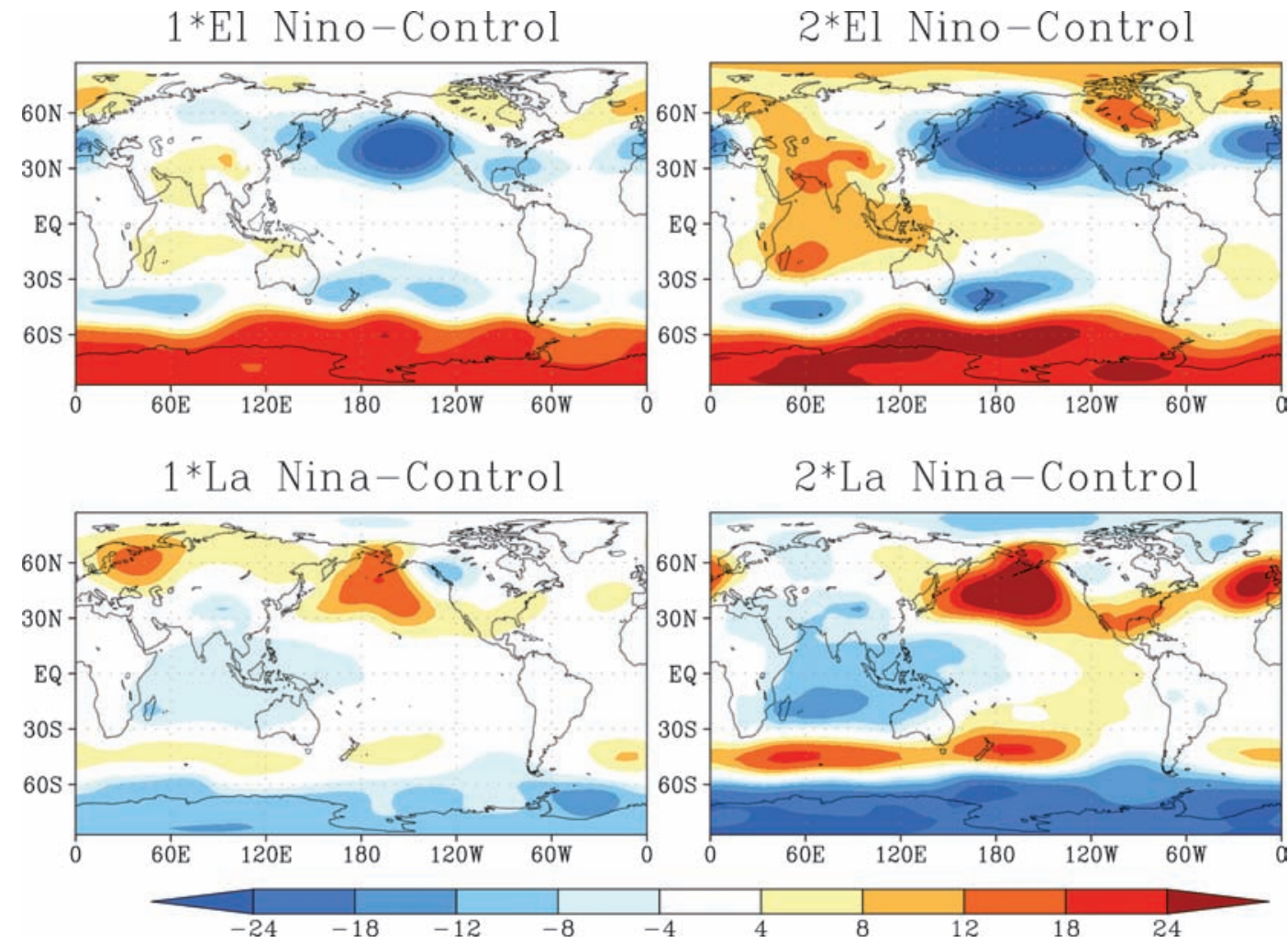

Figure 7. Ensemble mean response of geopotential height anomaly (experiment-control) at 850-hPa following El Niño and La Niña forcing in winter (DJF) season.

Niño condition both for $1 \times$ and $2 \times$ experiments, which indicates that La Niña will induce positive NAO-like pattern over the North Atlantic region that will result in cooling and drying anomalies over southern Europe and MENA region. Interestingly, the ENSO-induced NAO-like response over the North Atlantic Ocean is more pronounced for $2 \times$ El Niño and $2 \times$ La Niña and therefore associated changes over Europe and MENA are also significant for $2 \times$ ENSO phases than normal $1 \times$ ENSO episode. These results clearly reveal that the climatic impacts of ENSO over global and regional scales are very sensitive to the intensity of ENSO and its warming and cooling phases over the tropical Pacific. The SLP and associated geopotential height response in the north Pacific is caused as a result of a well-known winter ENSO teleconnection pattern induced by the Rossby wave source in the tropics that propagates towards extra-tropics and forms a quasi-barotropic structure. This wave train effect projects onto the Pacific North American (PNA) pattern, and the Aleutian low. This prominent teleconnection associated with ENSO events has been referred to as the PNA pattern accompanied by an intensified Aleutian low during ENSO warm (El Niño) phase. Corresponding to the ENSO (La Niña) cold phase, a positive SLP anomaly covers the North Pacific indicating a weakened Aleutian low during the La Niña events.
This type of pattern is anticipated to induce energy transport among tropics, extra-tropics and high-latitude regions following El Niño and La Niña forcing (Lee 2012). Figure 8 shows pattern of geopotential height at $200 \mathrm{hPa}$ following El Niño and La Niña forcing. This upper-level geopotential height anomaly is high in the tropics and low in the subtropical region because positive ENSO (El Niño phase) overall warms the tropical atmosphere and this leads to high geopotential anomalies in upper levels as a result of hydrostatic equilibrium. The height is lower in the more northern latitudes because of wave propagations of various types. This upper-level geopotential height anomaly is stronger over tropical Pacific compared to rest of the tropical regions both for $1 \times$ and $2 \times$ El Niño events which is associated with the El Niño-induced strong tropical Pacific warming pattern. These results are qualitatively consistent with observations and model-based Nino3.4 regressed anomalous pattern (Sterl et al. 2007; Kucharski et al. 2013a, b). Responses of geopotential height anomalies for $1 \times$ and $2 \times \mathrm{La}$ Niña episodes display a mirror image to their El Niño counterparts.

\subsection{Summer response}

Figures 9 and 10 show summer season SST and 2-m surface air temperature anomalies both for 
$1 *$ El Nino-Control

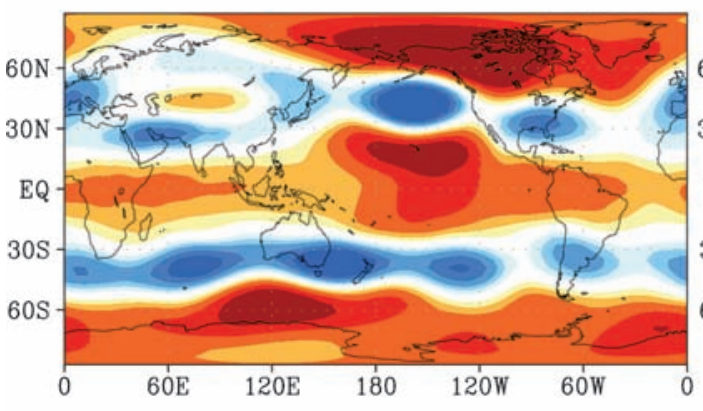

$1 *$ La Nina-Control

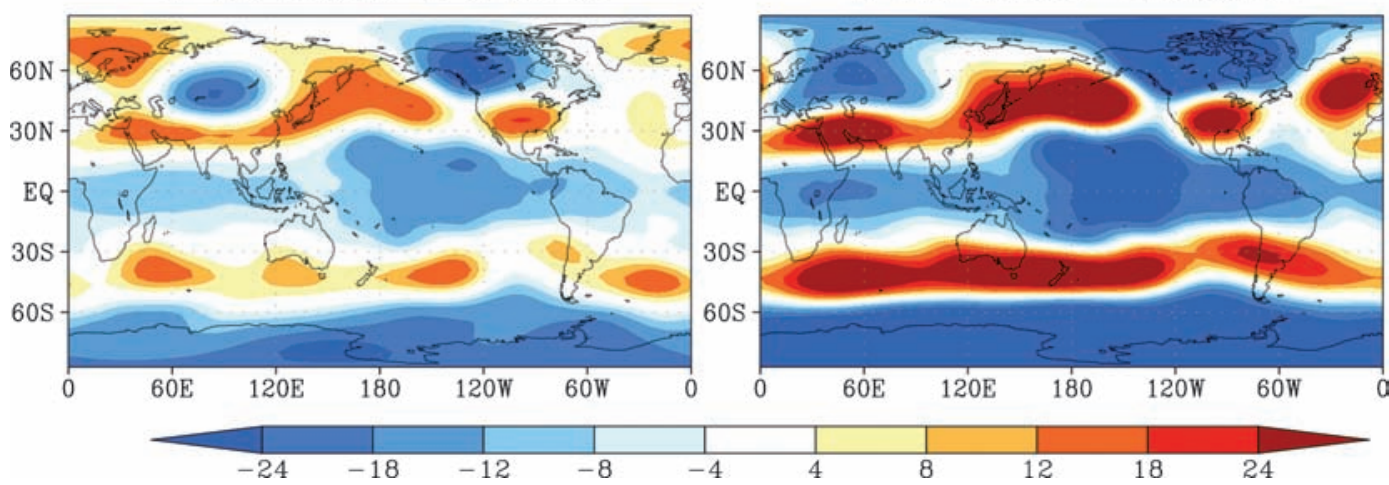

Figure 8. Ensemble mean response of geopotential height anomaly (experiment-control) at 200-hPa following El Niño and La Niña forcing in winter (DJF) season.
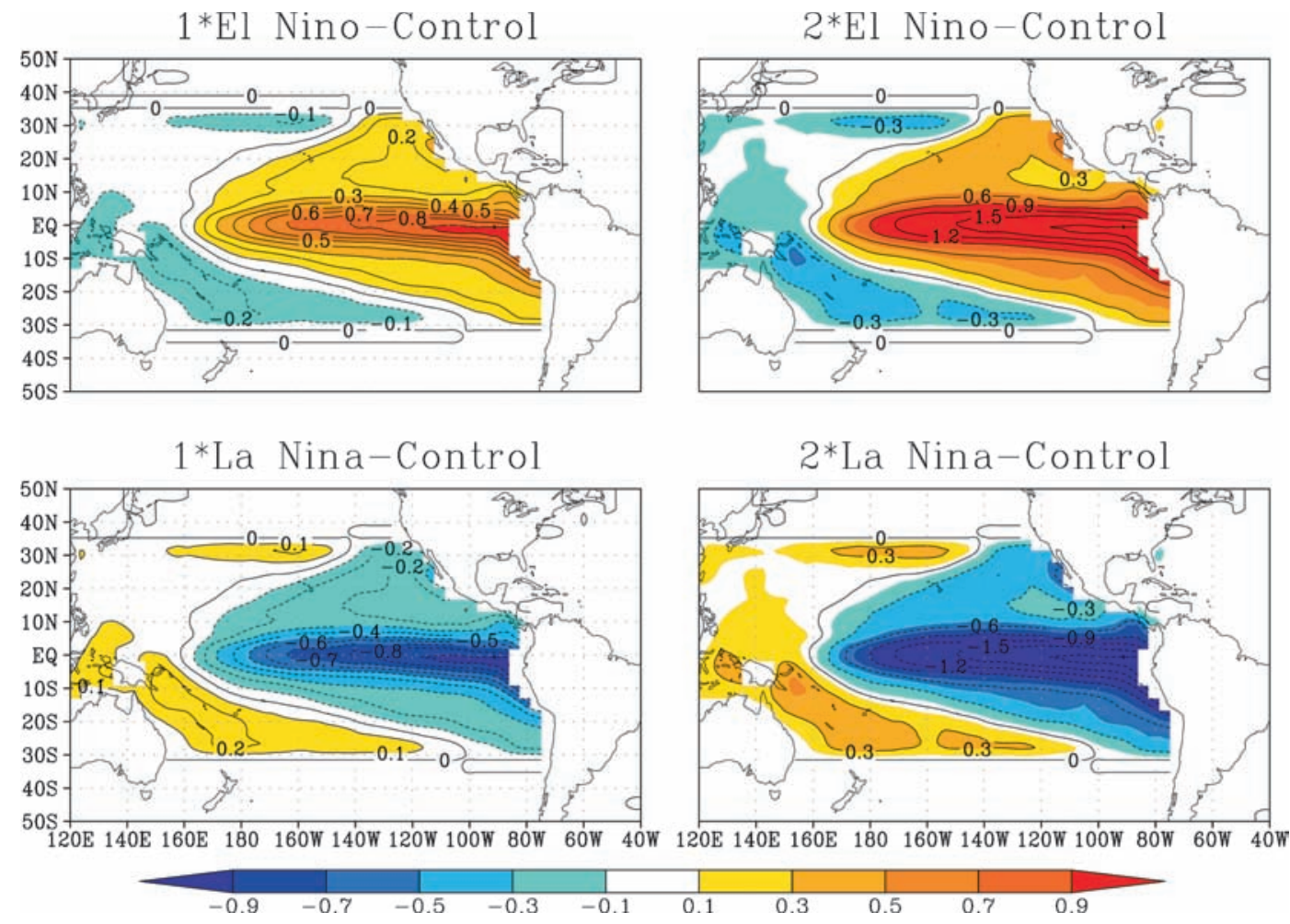

Figure 9. Mean SST anomaly pattern (experiment-control) in summer (JJA) season. 

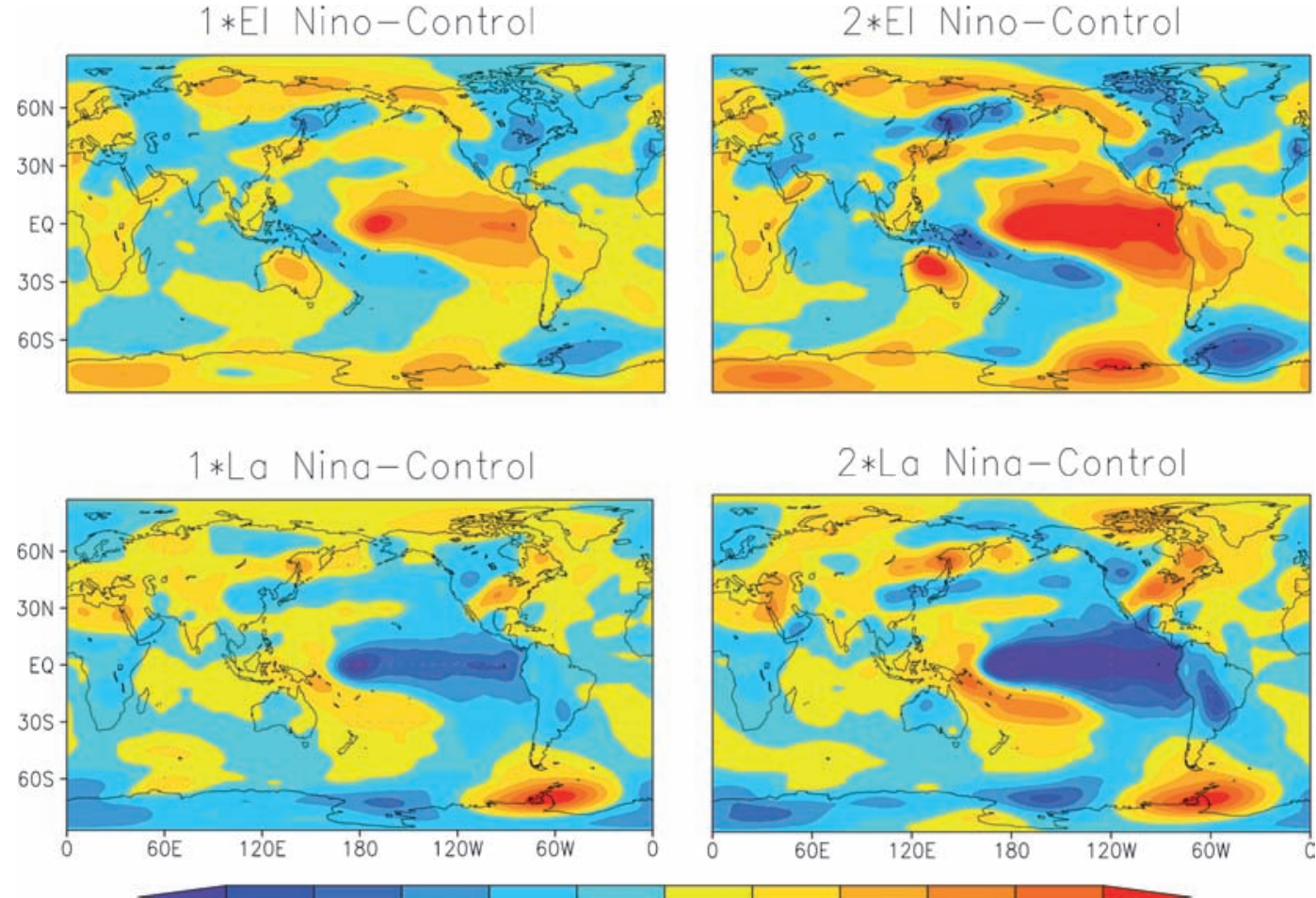

$\begin{array}{llll}-0.9 & -0.7 & -0.5 & -0.3\end{array}$
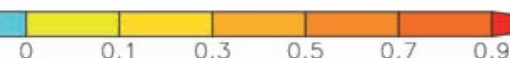

Figure 10. Ensemble mean response of 2-m surface air temperature anomaly pattern (experiment-control) following El Niño and La Niña forcing in summer (JJA) season.
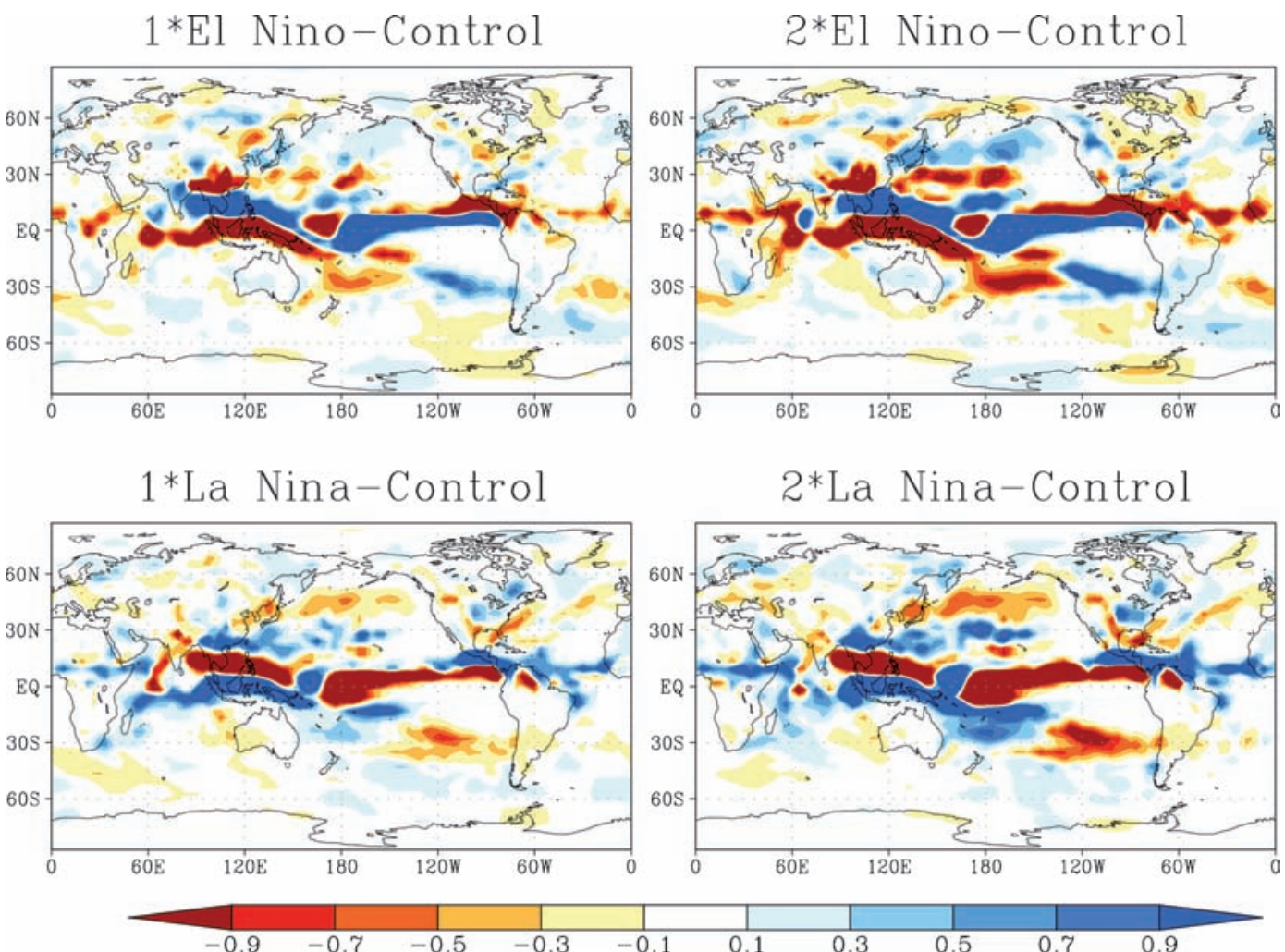

Figure 11. Ensemble mean response of precipitation $(\mathrm{mm} / \mathrm{d})$ anomaly (experiment-control) following El Niño and La Niña forcing in summer (JJA) season. 
$1 \times$ and $2 \times$ El Niño and La Niña conditions activated over the tropical Pacific Ocean. Cold and warm SST anomalies over the Pacific Ocean for El Niño and La Niña phases are well represented by SPEEDY model. The warming (cooling) response following El Niño (La Niña) over the North and South America and African domain including Arabian peninsula region is relatively weaker in summer than in winter, which indicates that both El Niño and La Niña forcing in summer season may induce weaker climatic impact than El Niño and La Niña phases in winter season. We noticed that El Niño-induced warming seen over North American region in winter season is shifted westward over the Arctic Ocean which shows that ENSOinduced wave pattern and associated lows and highs shift westward in summer season and their intensity is also weaker in summer than their winter counterpart.

Figure 11 shows the response of precipitation anomaly in summer season both for $1 \times$ and $2 \times$ El Niño and La Niña forcing scenarios. The simulated convection changes over the tropical Pacific closely follow spatial patterns of SST warming, consistent with the 'warmer-get-wetter' idea (Xie et al. 2010; Tokinaga et al. 2012). The spatial pattern of precipitation regime shows that El Niño is causing more rainfall anomaly over the tropical
ITCZ rain belt region which is somehow consistent with the warm anomaly pattern seen in $2 \mathrm{~m}$ temperature that results in more evaporation and moisture contents over oceans that subsequently follows the latitudinal movement of the upward (rising) branch of local Hadley cell. Interestingly, we noticed decreased rainfall anomaly over African ITCZ region (Sahel rain belt region) following El Niño particularly after $2 \times$ El Niño forcing scenario. This weakened precipitation anomaly could be a result of El Niño-induced weakening of African and Southeast Asian monsoon circulation. It is previously known that El Niño forcing causes warming over the tropical Indian and Atlantic Oceans and induces zonal temperature gradient through atmospheric overturning Walker circulation that results in more evaporation and associated rain over the Indian and Atlantic Oceans and a decreased rainfall towards inland areas of the Indian and African continents because of weak meridional thermal gradient (Kripalani et al. 2007). However, our idealized sensitivity experiments based on SST forcing over the tropical Pacific Ocean using SPEEDY model are not responding correctly to this El Niño-induced warming over the tropical Indian Ocean and therefore SPEEDY model overestimates precipitation changes over South Asia, in particular over Indian

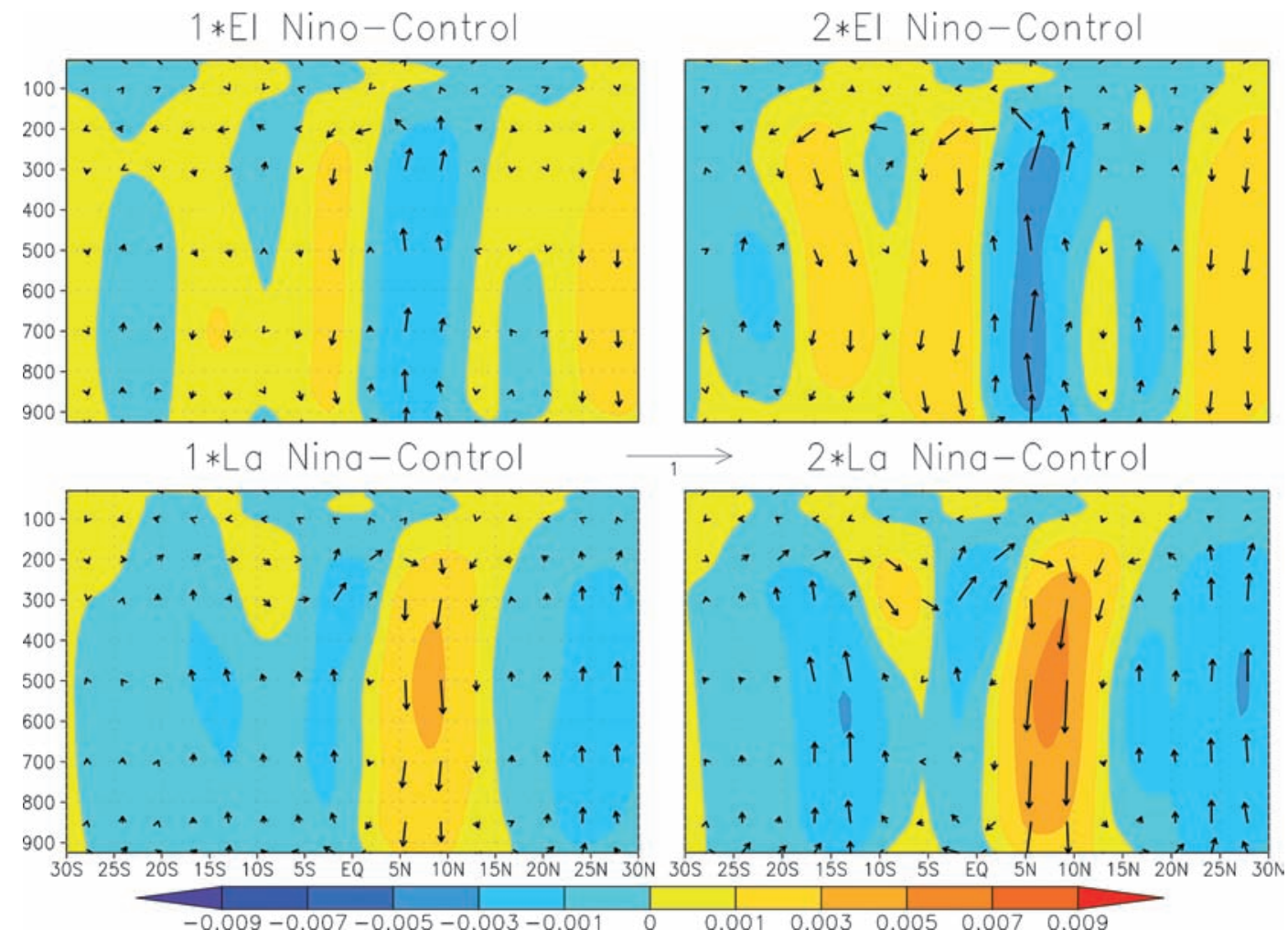

Figure 12. Ensemble mean anomaly (experiment-control) of zonal mean vertical velocity (Pa/s; in shaded colours) in the latitude pressure plane with overlaid zonal mean wind vectors (v; -100*omega) $[\mathrm{m} / \mathrm{s} ; 100 * \mathrm{~Pa} / \mathrm{s}]$ anomaly response (experiment-control) following El Niño and La Niña forcing in summer (JJA) season. The length and direction of arrows depict the intensity $(\mathrm{m} / \mathrm{s})$ and direction of air movement in the latitude pressure plane, respectively. 
and Sri Lankan regions. Consequently, SPEEDY produced features over the Indian Ocean and parts of associated South Asian regions are slightly inconsistent with earlier studies showing weaker monsoon circulation following El Niño forcing (Bracco et al. 2007; Kripalani et al. 2007; Lean and Rind 2008). This inconsistency could be related to the lack of interactive air-sea coupling in the Indian Ocean region in the SPEEDY simulation (Wu and Kirtman 2005; Wang et al. 2005; Bracco et al. 2007). Interestingly, maritime continents of Southeast Asian and Indo-Pacific domains are largely consistent with observations and earlier studies (Kucharski et al. 2013a, b). The La Niña forcing is showing opposite structure to the El Niño phase (figure 11, lower panel) over the entire globe, especially in the tropical Pacific and African Sahel region. However, the response over the tropical Indian Ocean, particularly in the Arabian Sea, the Bay of Bengal extending further towards Indian and Sri Lankan continents is somehow not well reflected. As discussed above, this disparity between SPEEDY simulation and earlier studies showing changes over Indian Ocean and inland South Asian continents could be accounted for by considering global SST forcing (Giannini et al. 2008) or by activating ENSO-induced tropical Indian Ocean SST anomaly pattern (Ashok et al. 2004) along with the tropical Pacific SST forcing, which implies that SST forcing over the tropical Indian Ocean in addition to tropical Pacific SST could be a potentially important driving factor (Bracco et al. 2007; Singh et al. 2013) to produce ENSO-induced teleconnection patterns over Southeast Asian region following El Niño and La Niña episodes. Figures 12 and 13 show ENSO-induced Hadley and Walker circulation responses for $1 \times$ and $2 \times$ El Niño and La Niña episodes. The rising and sinking limbs of Hadley cell are well represented by SPEEDY model, but their strength in summer is much weaker than their winter counterpart. Furthermore, the responses of Hadley circulation strengthened following increased magnitude of ENSO forcing which shows that El Niño overall causes strengthening of Hadley circulation. We noticed that ENSO-induced anomalies of Walker circulation are stronger and rising and sinking motion is much obvious over the tropical Pacific region than over the Indian Ocean, which shows that model is not responding well over the Indian Ocean, in particular over the Arabian Sea, Laccadive Sea and Bay of Bengal (figure 13). In addition, Walker circulation response following La Niña forcing over the Indian Ocean does not increase linearly with increased magnitude of
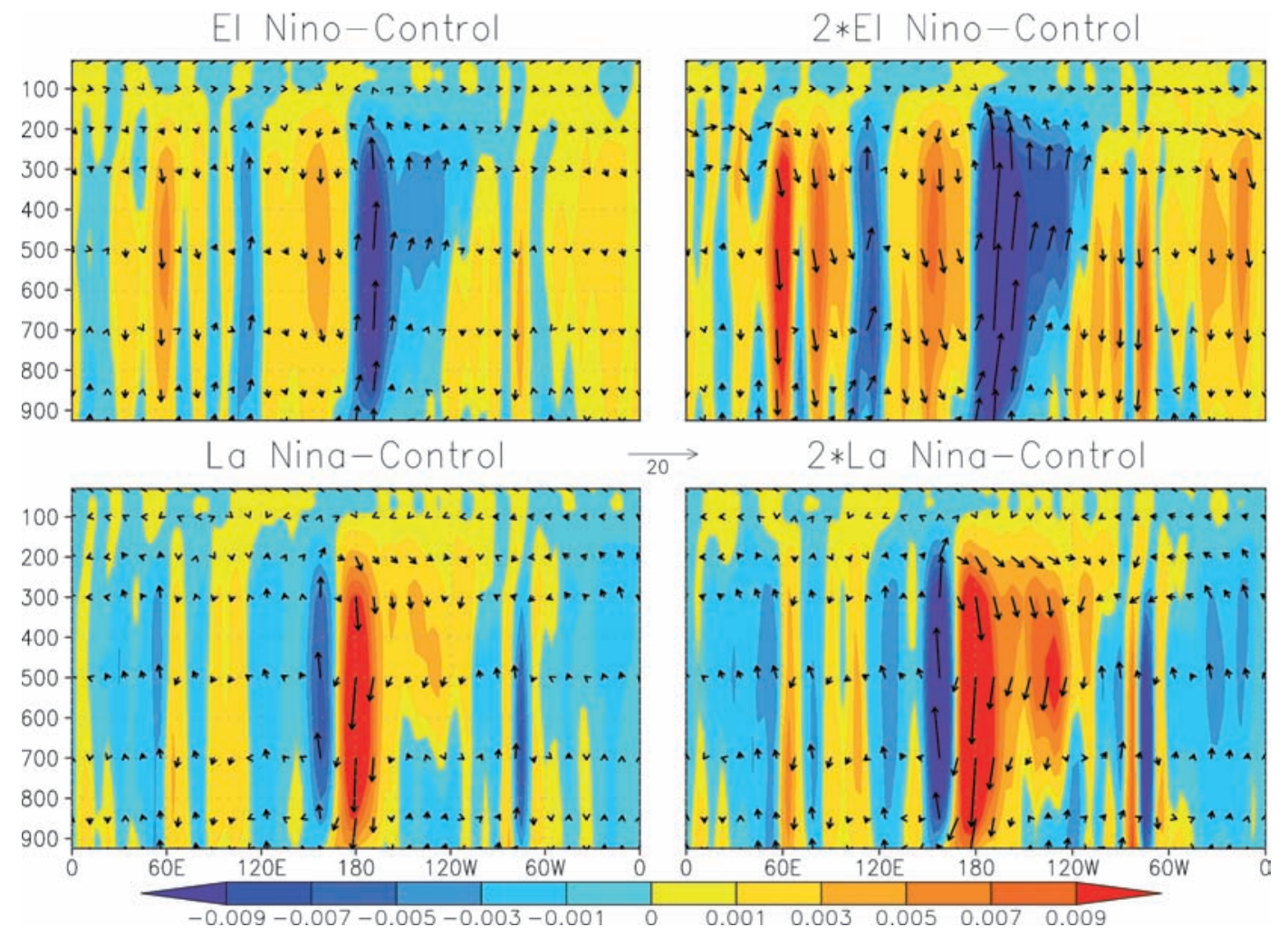

Figure 13. Ensemble mean anomaly (experiment-control) of meridional-mean $\left(20^{\circ} \mathrm{S}-20^{\circ} \mathrm{N}\right)$ vertical velocity $(\mathrm{Pa} / \mathrm{s})$ in the longitude pressure plane with overlaid meridional averaged $\left(20^{\circ} \mathrm{S}-20^{\circ} \mathrm{N}\right)$ wind vectors $(\mathrm{u} ;-1000 * \mathrm{omega})[\mathrm{m} / \mathrm{s} ; 1000 * \mathrm{~Pa} / \mathrm{s}]$ anomaly response (experiment-control) following El Niño and La Niña forcing in summer (JJA) season. The length and direction of arrows depict the intensity $(\mathrm{m} / \mathrm{s})$ and direction of air movement in the longitude pressure plane. 
La Niña. This type of response could explain further possibilities that why model underestimated over the Indian Ocean. Previous studies indicate that El Niño forcing scenario in summer induces intensification and equatorward shrinking to the Hadley cell circulation ( $\mathrm{Lu}$ et al. 2008; Nguyen et al. 2013 and references therein), and these features are also seen in our simulations showing Hadley cell response to ENSO forcing in winter and summer (figures 5 and 12). The negative phase of ENSO (La Niña) shows reverse feature and produces weakening and poleward expansion of the Hadley cell circulation. Both the earlier studies and a conventional wisdom suggest that ENSO (El Niño/La Niña)-induced changes in Walker circulation will result in warming/cooling over the tropical Indian Ocean that will result in weak/strong meridional thermal gradient that consequently results in less/more moisture transport towards inland areas of Africa and South Asia. The model produces these features over the African continent very well; however, it fails to show them over tropical South Asian continents in summer because it fails to produce Walkerinduced zonal warming pattern over Indian Ocean, especially in the Bay of Bengal region and hence, resultant precipitation patterns over tropical South Asian regions are less well reflected in SPEEDY.
However, drought conditions over African tropical Sahel region are well captured and model also somehow managed to produce decreased precipitation anomaly over central and Southern India following $2 \times$ El Niño event. La Niña episode will produce increased anomaly over African Sahel region in summer because La Niña will cause strong meridional temperature gradient that will drag more moisture through the inflow of moistureladen air from the Atlantic Ocean (Gulf of Guinea) into the interior of African continent, especially over the ITCZ rain belt region during the African monsoon. Effects over South Asian continents are slightly underestimating for La Niña episode as well because of the same reason discussed above. These results confirm that summer monsoon features in South Asian and African regions are very sensitive to ENSO-induced zonal and meridional thermal gradients caused by ENSOinduced variations in Hadley and Walker circulation changes. As Indian and African monsoon rainfall features are tightly coupled with ITCZ movement and therefore depend strongly upon strengthening or weakening of ITCZ. However, northward extent/position of this summer ITCZ (also known as upward branch of Hadley cell) varies at regional/local scale (i.e., it has different position and extent at different regions) and therefore

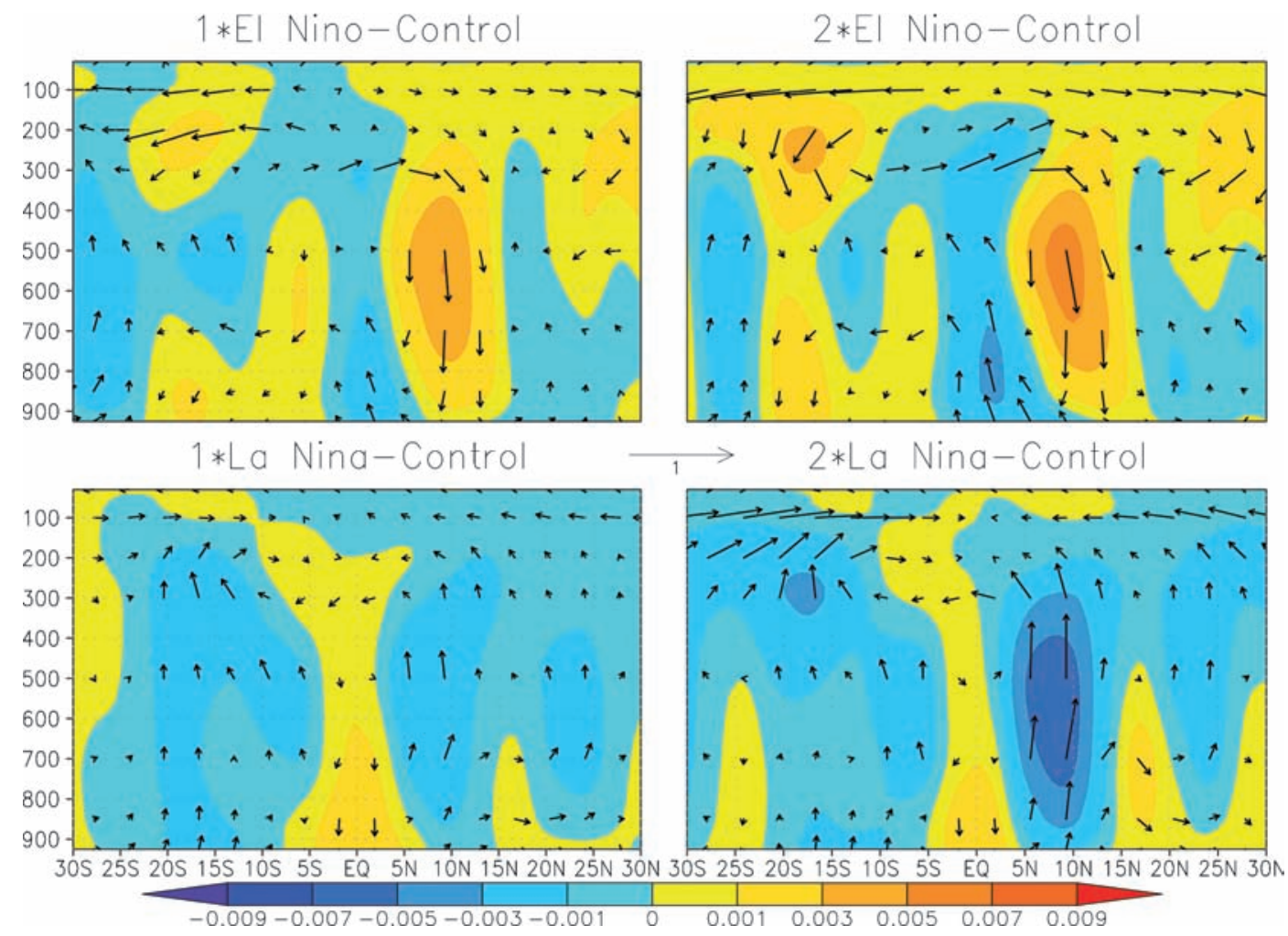

Figure 14. Ensemble mean anomaly (experiment-control) of zonal mean $\left(10^{\circ} \mathrm{W}-50^{\circ} \mathrm{E}\right)$ vertical velocity (Pa/s; in shaded colours) in the latitude pressure plane with overlaid zonal mean $\left(10^{\circ} \mathrm{W}-50^{\circ} \mathrm{E}\right)$ wind vectors $(\mathrm{v} ;-100 * \mathrm{omega})[\mathrm{m} / \mathrm{s} ; 100 * \mathrm{~Pa} / \mathrm{s}]$ anomaly response (experiment-control) following El Niño and La Niña forcing in summer (JJA) season. The length and direction of arrows depict the intensity $(\mathrm{m} / \mathrm{s})$ and direction of air movement in the latitude pressure plane, respectively. 

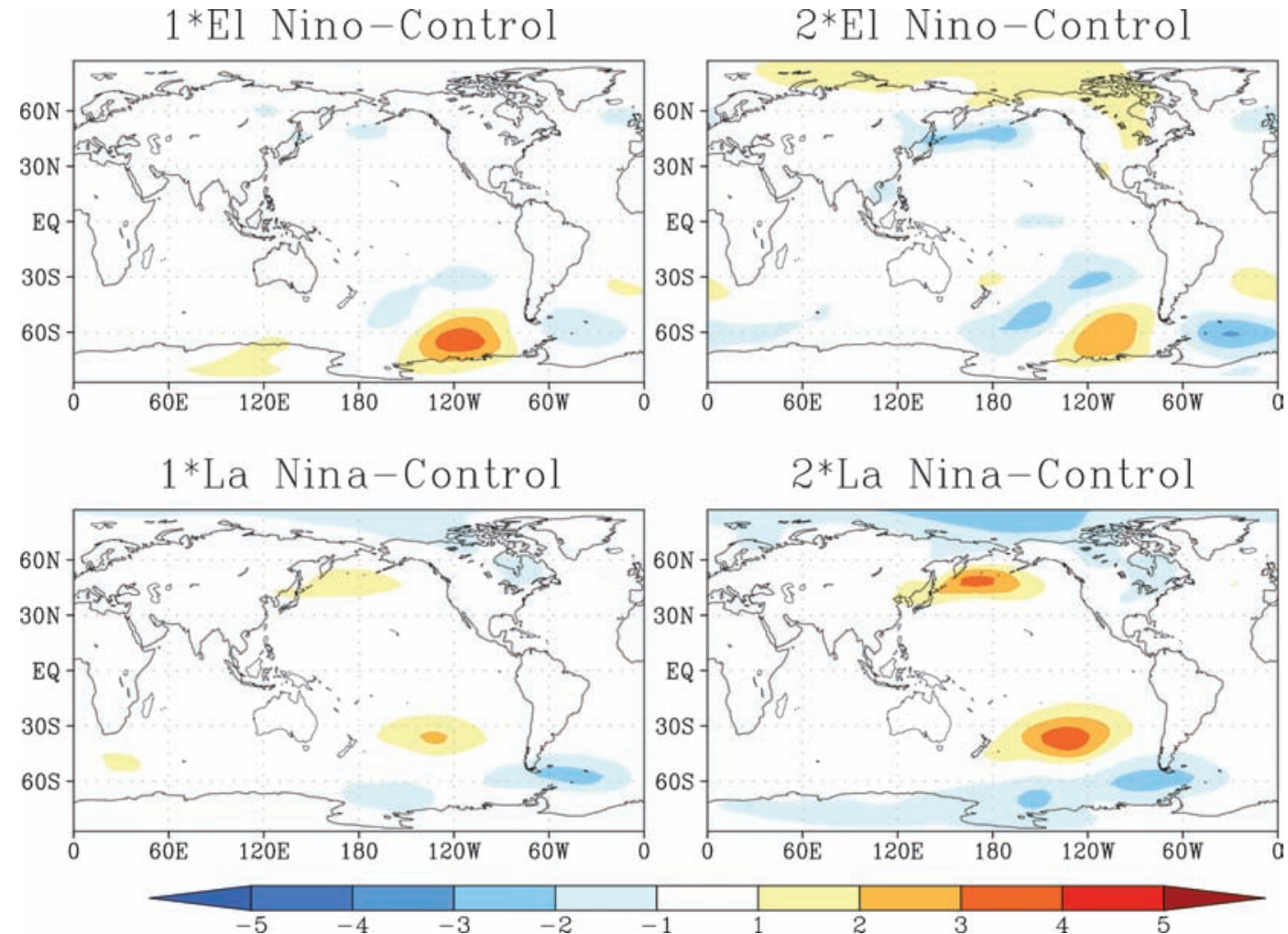

Figure 15. Ensemble mean response of mean sea level pressure (MSLP) anomaly (experiment-control) following El Niño and La Niña forcing in summer (JJA) season.
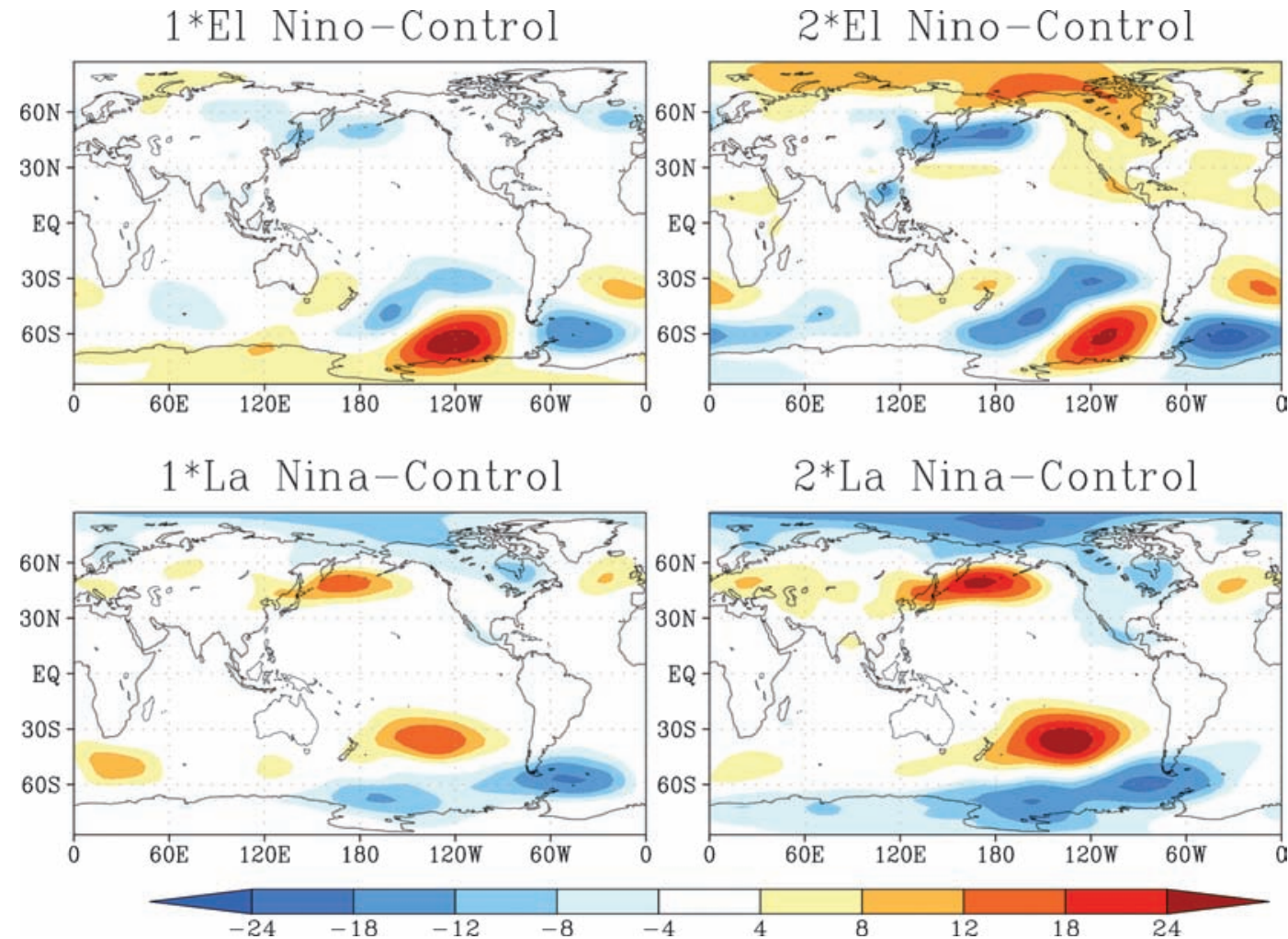

Figure 16. Ensemble mean response of geopotential height anomaly (experiment-control) at 850-hPa following El Niño and La Niña forcing in summer (JJA) season. 
to have better idea of ITCZ movement and associated changes in monsoonal rainfall, we need to look at Hadley cell response at local scale. We analyzed the pattern of Hadley cell over African tropical region (zonally averaged over $10^{\circ} \mathrm{W}-50^{\circ} \mathrm{E}$ ), which reveals that El Niño (La Niña) induces weakening (strengthening) to ITCZ over African tropical region (upward branch of Hadley cell is displaying a reversed pattern for El Niño/La Niña at about $6-15^{\circ} \mathrm{N}$ suggesting a weakening and equatorward movement) in summer (figure 14) that results in weakening of African monsoon system confirming that African and South Asian tropical regions are sensitive to tropically excited SST changes and associated thermal gradients.

Figures 15 and 16 show the response of mean sea level pressure and geopotential height anomalies at $850 \mathrm{hPa}$ following $\mathrm{El} \mathrm{Niño}$ and La Niña phases for both the experiments $(1 \times$ and $2 \times)$. Both the mean sea level pressure and geopotential height show weak response both at tropics and high latitudes. In boreal summer response of height in the Northern Hemisphere is weaker than in boreal winter that generates weaker Rossby waves resulting towards a weak poleward flow in the Southern Hemisphere. Instead, the wave propagation in the Southern Hemisphere is much clearer and stronger because it is winter season in the Southern Hemisphere. We further noticed that high and low pressure structures caused by Rossby waves in the Pacific Ocean are formulated in Southern Hemisphere instead of Northern Hemisphere that suggests that ENSOinduced NAO-like pattern seen in the Northern Hemisphere over the North Atlantic region in winter season could be established in Southern Atlantic Ocean in the summer season. Geopotential height at $200 \mathrm{hPa}$ (figure 17) shows strong response over the entire tropical belt especially over the tropical Pacific both for El Niño and La Niña forcing which is associated with El Niño (La Niña)induced tropical Pacific SST changes. This upperlevel height anomaly at the tropics is positive and shows cyclonic and anticyclonic flows at higher latitudes. Responses of geopotential height anomalies are stronger for $2 \times \mathrm{El}$ Niño and La Niña episodes compared to $1 \times$ ENSO. The anomalous response of geopotential height $(\mathrm{m})$ at upper-level is much
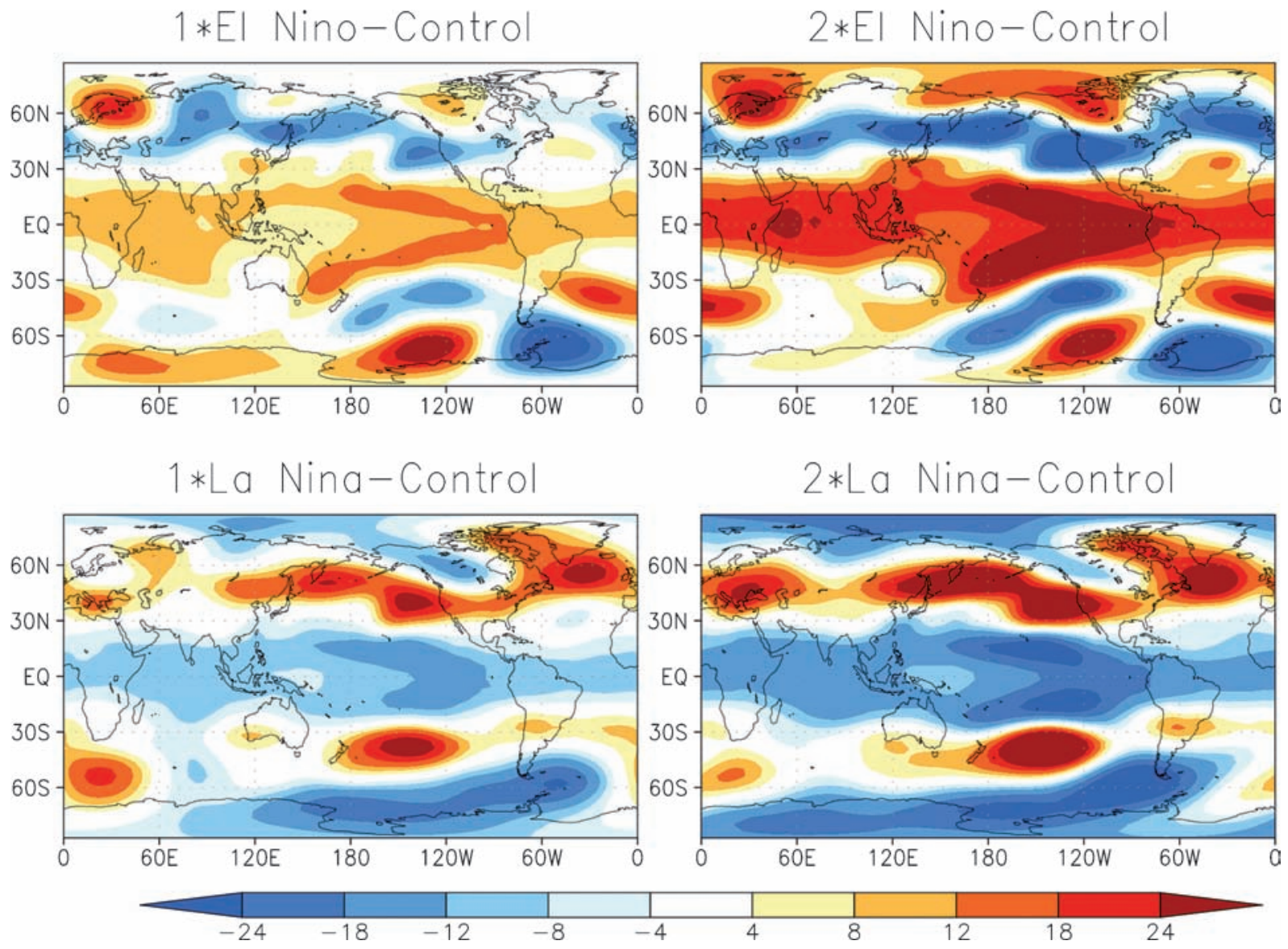

Figure 17. Ensemble mean response of geopotential height anomaly (experiment-control) at 200-hPa following El Niño and La Niña forcing in summer (JJA) season. 
weaker in summer season compared to winter season response, which confirms that ENSO impact in summer is weaker than in winter.

\section{Summary and conclusions}

Earlier studies suggest that both the frequency and magnitude of ENSO events have increased since last few decades resulting in a need to study global and regional climatic impacts of ENSO magnitude. The present study is an attempt to evaluate the role of ENSO magnitude in global and regional climate changes. The main progress for studying the ENSO events and their global and regional impacts came initially from models of intermediate complexity, which are sufficiently detailed to study such events and are computationally less demanding and less complex than coupled general circulation models. Hence, to better understand ENSO-induced climatic sensitivity at global and regional scales, we used SPEEDY ICTPAGCM and analyzed the impact of ENSO magnitude on 2-m surface air temperature, precipitation, sea level pressure, vertical wind and geopotential height at global and regional scale focussing on tropical and extra-tropical regions. Results obtained by SPEEDY atmospheric model show that ENSO has a stronger impact over the InterTropical Convergence Zone (ITCZ) region compared to extratropics and high latitude regions. The positive phase of ENSO causes weakening of rainfall over Africa, South Asia, whereas La Niña phase produces more rain over these regions particularly in the summer season. Model results further reveal that ENSO has a stronger impact on South Asia particularly over Indian region because of its significant impact over the Indian Ocean, especially over the Arabian Sea, the Bay of Bengal and the Laccadive Sea through Walker circulation. Results of precipitation anomalies, zonally averaged vertical wind, as well as geopotential height changes at 850 and $200 \mathrm{hPa}$ reveal that ENSO magnitude significantly impacts Hadley and Walker circulation. Model-based configuration of Hadley cell following doubled El Niño (La Niña) events emphasizes that the intensity of Hadley cell's rising and sinking branches increased (decreased) significantly exhibiting that the Hadley circulation is very sensitive to the magnitude of ENSO forcing. ENSO-induced changes in precipitation and vertical wind profile suggest that the positive phase of ENSO (El Niño) may induce strengthening and equatorward shrinking to Hadley cell, whereas the negative phase of ENSO (La Niña) cause weakening of Hadley cell both in the winter and the summer seasons. ENSObased sensitivity experiments further reveal that
El Niño (La Niña) induces significant weakening (strengthening) to local Hadley cell covering MENA and South Asian tropical regions which results in weakening (strengthening) of Indian and African monsoon systems indicating that MENA and South Asian tropical regions are very sensitive to tropically excited SST changes. This ENSO-induced strengthening/weakening of Hadley cell along with variations in Walker circulation induce significant impact over South/East Asian and African rain-belt regions. Our results reveal that both El Niño and La Niña forcing in summer (JJA) season induce weaker climatic impact than in winter season. Our study further shows that ENSO (El Niño/La Niña) causes strengthening (weakening) and equatorward (poleward) shift to jet streams. Analysis of MSLP and geopotential height changes suggest that ENSO-induced negative (positive) NAO-like response and associated changes over southern Europe and MENA region get significantly strong following increased intensity of El Niño (La Niña) in Northern (Southern) Hemisphere in boreal winter (summer) season. The SPEEDY model reproduces the impact of ENSO over the Pacific, North and South America and African regions quite well; however, it fails to effectively reproduce ENSO teleconnection patterns and associated changes in temperature and precipitation over South and Southeast Asia, especially in the Indian and Sri Lankan regions. It happens due to model's lack in well simulating the ENSO-induced thermal temperature pattern over the tropical Indian Ocean covering the Bay of Bengal, the Arabian Sea and the Laccadive Sea that resulted in marginally varying pattern of temperature and rainfall distribution in SPEEDY simulations over these regions. One of the possible reasons for this disparity could be that the SST forcing over the tropical Pacific might not be the only driving factor for major ENSO-based teleconnections and their global interactions. Our study suggests that ENSO-induced changes in SST over the tropical Indian Ocean could play significant role for governing teleconnections through changes in Walker circulation that consequently induces changes in meridional thermal gradient and affects monsoon circulation. This study further concludes that SST forcing over the tropical Indian and the Pacific Ocean and their teleconnection through largescale zonal atmospheric overturning circulation is attributed to be a potentially important driving condition to characterize ENSO-induced climatic changes over South Asia. ENSO-induced climatic conditions over south Asian region, especially in the Indian region are not well reproduced by SPEEDY AGCM, which suggests that Indian Ocean SST together with interactive air-sea coupling in the Indian Ocean should be taken into 
account for better representation of South and Southeast Asian monsoon features. In general, ENSO-induced global and regional teleconnection patterns of surface temperature, precipitation, SLP and geopotential height changes are consistent with earlier studies, which indicate that SPEEDY AGCM can be used effectively to better understand ENSO-induced global and regional climatic responses.

\section{Acknowledgements}

We would like to thank the editor and two anonymous reviewers whose constructive suggestions and comments significantly improved the manuscript. We are also thankful to the Abdus Salam International Centre for Theoretical Physics (ICTP), Trieste, Italy, for providing computational facilities and technical support to perform the experiments at ICTP computer lab. The first author is supported by King Abdullah University of Science and Technology (KAUST), Thuwal, Saudi Arabia. The simulation results and figures are available from the authors on request.

\section{References}

Ashok K, Guan Z and Yamagata T 2001 Impact of the Indian Ocean dipole on the relationship between the Indian monsoon rainfall and ENSO; Geophys. Res. Lett. 28(23) 4499-4502.

Ashok K, Guan Z, Saji N H and Yamagata T 2004 Individual and combined influences of ENSO and the Indian Ocean dipole on the Indian summer monsoon; J. Climate 17(16) 3141-3155.

Ashok K, Behera S K, Rao S A, Weng H and Yamagata T 2007 El Niño Modoki and its possible teleconnection; J. Geophys. Res. Oceans 112(C11).

Barimalala R, Bracco A and Kucharski F 2012 The representation of the south tropical Atlantic teleconnection to the Indian Ocean in the AR4 coupled models; Clim. Dyn. 38(5-6) 1147-1166.

Bhalme H N and Mooley D A 1980 Large-scale droughts/floods and monsoon circulation; Mon. Wea. Rev. 108(8) 1197-1211.

Bourke W 1974 A multilevel spectral model. I: Formulation and hemispheric integrations; Mon. Wea. Rev. 102 687-701.

Bracco A, Kucharski F, Molteni F, Hazeleger W and Severijns C 2007 A recipe for simulating the interannual variability of the Asian summer monsoon and its relation with ENSO; Clim. Dyn. 28(5) 441-460.

Brönnimann S, Xoplaki E, Casty C, Pauling A and Luterbacher J 2007 ENSO influence on Europe during the last centuries; Clim. Dyn. 28(2-3) 181-197.

Bulić I H and Branković Ć 2007 ENSO forcing of the Northern Hemisphere climate in a large ensemble of model simulations based on a very long SST record; Clim. Dyn. 28(2-3) 231-254.

Bulić I H and Kucharski F 2012 Delayed ENSO impact on spring precipitation over North/Atlantic European region; Clim. Dyn. 38(11-12) 2593-2612.
Bulić I H, Branković Č and Kucharski F 2012 Winter ENSO teleconnections in a warmer climate; Clim. Dyn. 38(7-8) 1593-1613.

Diaz H F, Hoerling M P and Eischeid J K 2001 ENSO variability, teleconnections and climate change; Int. J. Climatol. 21(15) 1845-1862.

Feng J and Li J 2013 Contrasting impacts of two types of ENSO on the boreal spring Hadley circulation; J. Climate 26(13) 4773-4789.

Giannini A, Biasutti M and Verstraete M M 2008 A climate model-based review of drought in the Sahel: Desertification, the re-greening and climate change; Global Planet. Change 64(3) 119-128.

Held I M and Hou A Y 1980 Nonlinear axially symmetric circulations in a nearly inviscid atmosphere; J. Atmos. Sci. 37(3) 515-533.

Held I M and Suarez M J 1994 A proposal for the intercomparison of the dynamical cores of atmospheric general circulation models; Bull. Am. Meteorol. Soc. $\mathbf{7 5}$ $1825-1830$.

Ineson S and Scaife A 2009 The role of the stratosphere in the European climate response to El Niño; Nature Geosci. 2(1) $32-36$.

Jin F and Hoskins B J 1995 The direct response to tropical heating in a baroclinic atmosphere; J. Atmos. Sci. 52(3) 307-319.

Ju J and Slingo J 1995 The Asian summer monsoon and ENSO; Quart. J. Roy. Meteorol. Soc. 121(525) 1133-1168.

Kao H-Y and Yu J-Y 2009 Contrasting eastern-Pacific and central-Pacific types of ENSO; J. Climate 22(3) 615632.

Karori M A, Li J and Jin F-F 2013 The asymmetric influence of the two types of El Niño and La Niña on summer rainfall over Southeast China; J. Climate 26(13) 4567-4582.

Kiladis G N, Wheeler M C, Haertel P T, Straub K H and Roundy P E 2009 Convectively coupled equatorial waves; Rev. Geophys. 47(2), doi: 10.1029/2008RG000266.

Kripalani R, Oh J, Kulkarni A, Sabade S and Chaudhari H 2007 South Asian summer monsoon precipitation variability: Coupled climate model simulations and projections under IPCC AR4; Theoret. Appl. Climatol. 90(3-4) 133-159.

Kucharski F, Molteni F and Bracco A 2006a Decadal interactions between the western tropical Pacific and the North Atlantic oscillation; Clim. Dyn. 26(1) 79-91.

Kucharski F, Molteni F and Yoo J H 2006b SST forcing of decadal Indian monsoon rainfall variability; Geophys. Res. Lett. 33(3), doi: 10.1029/2005GL025371.

Kucharski F, Bracco A, Yoo J H and Molteni F 2007 Low-frequency variability of the Indian monsoon-ENSO relationship and the tropical Atlantic: The 'weakening' of the 1980s and 1990s; J. Climate 20(16) 42554266.

Kucharski F, Zeng N and Kalnay E 2013a A further assessment of vegetation feedback on decadal Sahel rainfall variability; Clim. Dyn. 40(5-6) 1453-1466.

Kucharski F, Molteni F, King M P, Farneti R, Kang I S and Feudale L 2013b On the need of intermediate complexity general circulation models: A 'SPEEDY' example; Bull. Am. Meteorol. Soc. 94(1) 25-30.

Kug J-S, Jin F-F and An S-I 2009 Two types of El Niño events: Cold tongue El Niño and warm pool El Niño; J. Climate 22(6) 1499-1515.

Kumar K K, Rajagopalan B and Cane M A 1999a On the weakening relationship between the Indian monsoon and ENSO; Science 284(5423) 2156-2159.

Kumar K K, Kleeman R, Cane M A and Rajagopalan B 1999b Epochal changes in Indian monsoon-ENSO precursors; Geophys. Res. Lett. 26(1) 75-78. 
Larkin N K and Harrison D E 2005 On the definition of El Niño and associated seasonal average US weather anomalies; Geophys. Res. Lett. 32(13), doi: 10.1029/2005GL022738.

Latif M, Kleeman R and Eckert C 1997 Greenhouse warming, decadal variability, or El Niño? An attempt to understand the anomalous 1990s; J. Climate 10(9) 2221-2239.

Lau N C and Nath M J 2000 Impact of ENSO on the variability of the Asian-Australian monsoons as simulated in GCM experiments; J. Climate 13(24) 4287-4309.

Lean J L and Rind D H 2008 How natural and anthropogenic influences alter global and regional surface temperatures: 1889 to 2006; Geophys. Res. Lett. 35(18) L18701, doi: 10.1029/2008GL0348.

Lee S 2012 Testing of the tropically excited Arctic warming mechanism (TEAM) with traditional El Niño and La Niña; J. Climate 25(12) 4015-4022.

Lee S K, Wang C and Enfield D B 2010 On the impact of central Pacific warming events on Atlantic tropical storm activity; Geophys. Res. Lett. 37 L17702, doi: 10.1029/2010GL04445.

Lu J, Chen G and Frierson D M W 2008 Response of the zonal mean atmospheric circulation to El Niño versus global warming; J. Climate 21 5836-5851.

Molteni F 2003 Atmospheric simulations using a GCM with simplified physical parametrizations. I. Model climatology and variability in multi-decadal experiments; Clim. Dyn. 20 175-191.

Molteni F, Corti S, Ferranti L and Slingo J M 2003 Predictability experiments for the Asian summer monsoon: Impact of SST anomalies on interannual and intraseasonal variability; J. Climate 16 4001-4021.

Molteni F, King M P, Kucharski F and Straus D M 2011 Planetary-scale variability in the northern winter and the impact of land-sea thermal contrast; Clim. Dyn. 37(1-2) 151-170.

Neelin J D, Battisti D S, Hirst A C, Jin F F, Wakata Y, Yamagata T and Zebiak S E 1998 ENSO theory; J. Geophys. Res.: Oceans 103(C7) 14261-14290.

Nguyen H, Evans A, Lucas C, Smith I and Timbal B 2013 The Hadley circulation in reanalyses: Climatology, variability, and change; J. Climate 26(10) $3357-$ 3376.

Pant G B and Parthasarathy B 1981 Some aspects of an association between the southern oscillation and Indian summer monsoon; Arch. Meteorol. Geophys. Biokl., Sr. B $29245-251$.

Parthasarathy B, Rupa Kumar K and Munot A A 1991 Evidence of secular variations in Indian summer monsoon rainfall-circulation relationships; J. Climate 4 927-938.

Parthasarathy B, Kumar K R and Kothawale D R 1992 Indian summer monsoon rainfall indices: 1871-1990; Meteorol. Mag. 121 174-186.

Parthasarathy B, Munot A A and Kothawale D R 1994 AllIndia monthly and summer rainfall indices: 1871-1993; Theor. Appl. Climatol. 49 219-224.

Rasmusson E M and Carpenter T H 1983 The relationship between eastern equatorial Pacific sea surface temperatures and rainfall over India and Sri Lanka; Mon. Wea. Rev. 111(3) 517-528.

Saha S, Moorthi S, Pan H-L, Wu X, Wang J, Nadiga S, Tripp P, Kistler R, Woollen J and Behringer D 2010 The NCEP climate forecast system reanalysis; Bull. Am. Meteorol. Soc. 91(8) 1015-1057.
Saravanan R 1993 Equatorial superrotation and maintenance of the general circulation in two-level models; J. Atmos. Sci. 50 1211-1227.

Schwendike J, Govekar P, Reeder M J, Wardle R, Berry G $\mathrm{J}$ and Jakob C 2014 Local partitioning of the overturning circulation in the tropics and the connection to the Hadley and Walker circulations; J. Geophys. Res.: Atmos. 119(3) 1322-1339.

Seager R, Harnik N, Kushnir Y, Robinson W and Miller J 2003 Mechanisms of hemispherically symmetric climate variability; J. Climate 16(18) 2960-2978.

Shukla J and Paolino D A 1983 The southern oscillation and long-range forecasting of the summer monsoon rainfall over India; Mon. Wea. Rev. 111(9) 1830-1837.

Singh P, Chowdary J S and Gnanaseelan C 2013 Impact of prolonged La Niña events on the Indian Ocean with a special emphasis on southwest tropical Indian Ocean SST; Global Planet. Change 100 28-37.

Smith T M, Reynolds R W, Peterson T C and Lawrimore J 2008 Improvements to NOAA's historical merged land-ocean surface temperature analysis (1880-2006); J. Climate 21(10) 2283-2296.

Sterl A, van Oldenborgh G J, Hazeleger W and Burgers G 2007 On the robustness of ENSO teleconnections; Clim. Dyn. 29(5) 469-485.

Timmermann A, Oberhuber J, Bacher A, Esch M, Latif M and Roeckner E 1999 Increased El Niño frequency in a climate model forced by future greenhouse warming; Nature 398(6729) 694-697.

Tokinaga H, Xie S P, Deser C, Kosaka Y and Okumura Y M 2012 Slowdown of the Walker circulation driven by tropical Indo-Pacific warming; Nature 491(7424) 439-443.

Trenberth K E and Caron J M 2000 The southern oscillation revisited: Sea level pressure, surface temperatures, and precipitation; J. Climate 13 4358-4365.

Trenberth K E, Branstator G W, Karoly D, Kumar A, Lau N C and Ropelewski C 1998 Progress during TOGA in understanding and modeling global teleconnections associated with tropical sea surface temperatures; J. Geophys. Res.: Oceans 103(C7) 14291-14324.

Walker G T 1925 Correlation in seasonal variations of WEATHER - A further study of world WEATHER 1; Mon. Wea. Rev. 53(6) 252-254.

Wang B, Ding Q, Fu X, Kang I S, Jin K, Shukla J and Doblas-Reyes F 2005 Fundamental challenge in simulation and prediction of summer monsoon rainfall; Geophys. Res. Lett. 32 L15711, doi: 10.1029/2005GL0227.

Wang C, Deser C, Yu J Y, DiNezio P and Clement A 2012 El Niño and southern oscillation (ENSO): A review; Coral reefs of the Eastern Pacific, pp. 3-19.

Wu R and Kirtman B P 2005 Roles of Indian and Pacific Ocean air-sea coupling in tropical atmospheric variability; Clim. Dyn. 25(2-3) 155-170.

Xie S P, Deser C, Vecchi G A, Ma J, Teng H and Wittenberg A T 2010 Global warming pattern formation: sea surface temperature and rainfall; J. Climate 23(4) 966-986.

Yeh S W, Kug J S, Dewitte B, Kwon M H, Kirtman B P and Jin F F 2009 El Niño in a changing climate; Nature 461(7263) 511-514.

Yu J Y and Kim S T 2010 Three evolution, patterns of central Pacific El Niño; Geophys. Res. Lett. 37 L08706, doi: 10.1029/2010GL042810.

$\mathrm{Yu}$ R and Zhou T 2004 Impacts of winter NAO on March cooling trends over subtropical Eurasia continent in the recent half century; Geophys. Res. Lett. 31 L12204, doi: 10.1029/2004GL0198. 
Zeng N 2003 Drought in the Sahel; Science 302(5647) 999-1000.

Zhang W J, Jin F-F, Li J P and Ren H-L 2011 Contrasting impacts of two-type El Niño over the western North Pacific during boreal autumn; J. Meteorol. Soc. Japan 89 563-569.

Zhang W J, Jin F F, Ren H L, Li J P and Zhao J X 2012 Differences in teleconnection over the North Pacific and rainfall shift over the USA associated with two types of
El Niño during boreal autumn; J. Meteorol. Soc. Japan $90535-552$.

Zhang W, Jin F F, Zhao J X, Qi L and Ren H L 2013 The possible influence of a nonconventional El Niño on the severe autumn drought of 2009 in Southwest China; J. Climate 26(21) 8392-8405.

Zhang W, Wang L, Xiang B, Qi L and He J 2015 Impacts of two types of La Niña on the NAO during boreal winter; Clim. Dyn. 44(5-6) 1351-1366.

MS received 15 June 2016; revised 7 October 2016; accepted 7 November 2016

Corresponding editor: A K SAHAI 